\title{
Efficiency Improvement Methods of Gas Turbine
}

\author{
R. Espanani ${ }^{1}$, S.H.Ebrahimi ${ }^{2}$, H.R.Ziaeimoghadam ${ }^{3, *}$ \\ ${ }^{1}$ Iran power development Co., Tehran, Iran \\ ${ }^{2}$ Islamic azad university, science and research branch, mechanical department, Tehran, Iran \\ ${ }^{3}$ Islamic azad university, science and research branch, mechanical department, Tehran, Iran \\ *Corresponding Author: ziaeimoghadam@iauln.ac.ir
}

Copyright $@ 2013$ Horizon Research Publishing All rights reserved.

\begin{abstract}
gas turbines are machines that work directly with ambient air, then anything that causes a change in the inlet air condition, effect on turbine efficiency. Relative humidity, Mean sea level and environment temperature have a direct effect on gas turbine efficiency.Generally, peak demand for electricity occurs during the summer time, that the output power of the gas turbine reaches its minimum value for high temperature of inlet air. This makes a lot of pressure on the power industry and to compensate for excess demand, there will always be a need for further investment of new plants. Research done on V94.2 turbines manufactured by Siemens and for pilot studies, thermo flow and GT Pro software was used.
\end{abstract}

Keywords Gas Turbine, Efficiency, Power Plant

\section{Introduction}

Turbine power output and efficiency factors include ambient air temperature, relative humidity, Mean sea level, inlet air pressure and fuel type that can decrease outlet power of gas turbine rather than design condition (ISO condition). inlet air temperature and Mean sea level of installation place have most effect on application parameters of turbine that mean sea level cannot be ignored and all outlet power enhancement methods and efficiency improvement Concentrated on inlet air cooling. comparing with new power plant construction costs, apply inlet air cooling methods are less expensive that cause outlet power of gas turbine become closer to nominal power and a significant portion of excess demand will be compensated. in more operating gas turbine, cooling inlet air is under consideration because it is an independence process. this method without any change or modification in main components of gas turbine and considering some technical point is applicable. However Installation location of its equipments is almost independent and separate from main components of gas turbine cycle, all of these cooling inlet air methods are applicable during design, manufacturing or installing. Power enhancement and efficiency improvement of gas methods is mainly divided into three very general categories were

a) power enhancement method by inlet air cooling

b) efficiency improvement and power enhancement methods by using outlet hot gas

c) saving energy methods

first and second category except using outlet hot gas in absorption chillers for cooling inlet air, all methods need changes in combustion turbine cycle that need turbine design parameters and its thermodynamic conditions. Therefore applying these methods is only possible for companies that access to the turbine design conditions. Considering this restriction, preconditions of power enhancements using inlet air cooling method [1, 2], investigated and determined. it should be taken into by technical-economical criteria and final score to determine optimal method of each power plant, because it can't be expressed by considering only technical advantage of one method or lower cost of another one.

Therefore considering advantages of inlet air cooling methods [3], we technically and economically investigate evaporation, compression refrigeration, absorption refrigeration and fogging method $[4,5,6]$ in efficiency improvement of V94.2 gas turbine using thermo flow and GT Pro software. We will briefly explain each of them following:

a) Water is evaporated in the compressor inlet air duct in evaporation methods. Thus latent heat of water evaporation is token from air and air is cooled. Reducing the maximum inlet temperature to the dew point or vapor saturation point temperature is fundamental limits and lower primary and operating costs is its benefits of these methods.

b) In method of compression refrigeration, a radial or impact chiller is used to cooling compressor inlet air by a cooling coil or placing evaporator in air path. Primary cost and especially high operating cost and energy consumption is disadvantages of this method but independent from environmental condition is benefits of this method.

c) To cool compressor inlet air, an absorption chiller with Liquid refrigerant has been used in absorption refrigeration method. High Primary cost is the problem of this method and lower energy consumption, low operating cost and independence from environmental condition is benefits of 
this method.

In high pressure fog spray in inlet air ducts method, water particles are sprayed into the air intake duct. These fine particles of water, by heat absorbing, evaporated and cause cooling the inlet air compressor. On the other hand, the addition of water to the air, which increases flow density, cause power output will increase It should be mentioned, overspray method for this turbine, by using the software is not recommended. To analyze efficiency improvement method using Thermo flow software, three different methods of evaporation, fog spray and compression and absorption refrigeration (which are divided into four methods) were selected.

Also for better Comparison of efficiency improvement methods and effects of environmental factors on turbine outlet, V94.2 turbine already installed sites, Khorramshahr and Sanandaj is selected. Furthermore, in order to better analyze the results, applied conditions on efficiency improvement systems for both sites is considered as same.
For better Comparison of efficiency improvement methods and effects of environmental factors on turbine outlet, V94.2 turbine already installed sites, Khorramshahr and Sanandaj is selected. Furthermore, in order to better analyze the results, applied conditions on efficiency improvement systems for both sites is considered as same that comes in following.

\section{Results of Apply Different Method of Efficiency Improvement on Sanadaj Power Plant}

\subsection{Apply Evaporative Cooling Method [7, 8]}

A 5 degree reduction in temperature and 43 percent increasing humidity system is used to apply evaporative cooling method by simulation software. This is shown in figure 1 .

\section{Methodology}

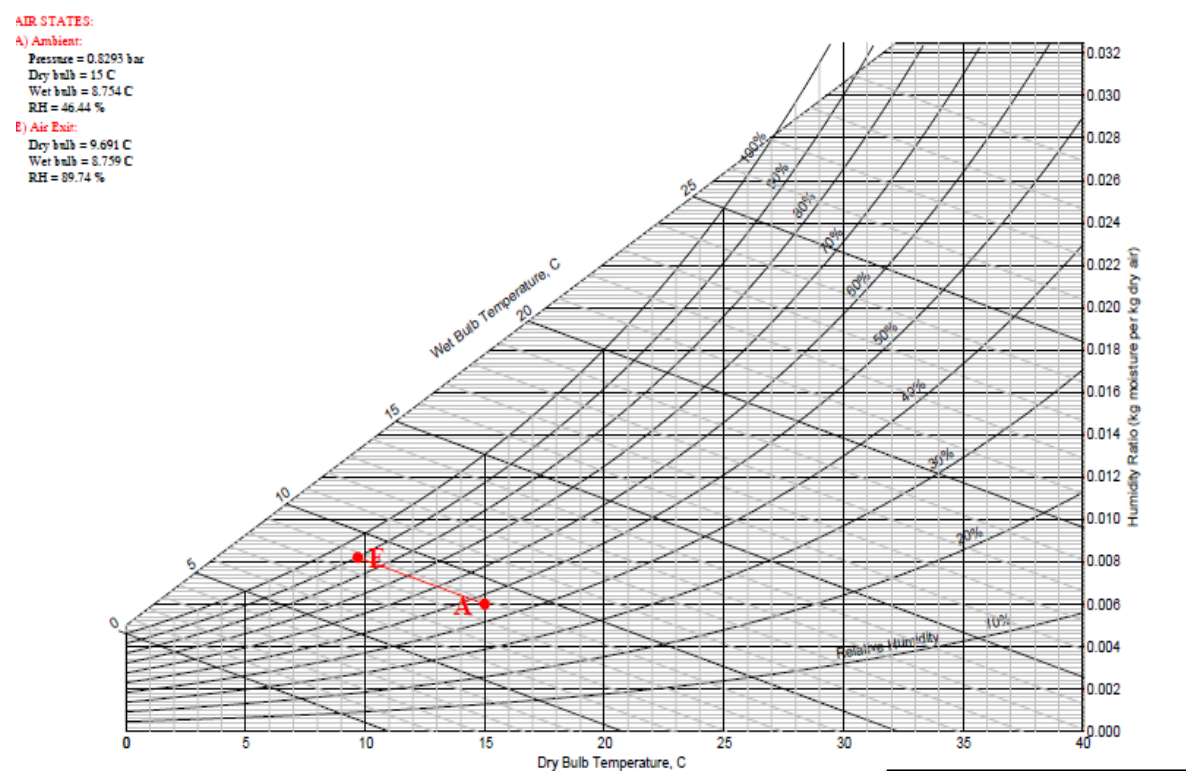

Figure 1. Cooling system specifications

\subsection{Apply Fogging Method $[4,5,6]$}

A 5 degree reduction in temperature and 43 percent increasing humidity system is used to apply fogging method by simulation software. This is shown in figure 2. 


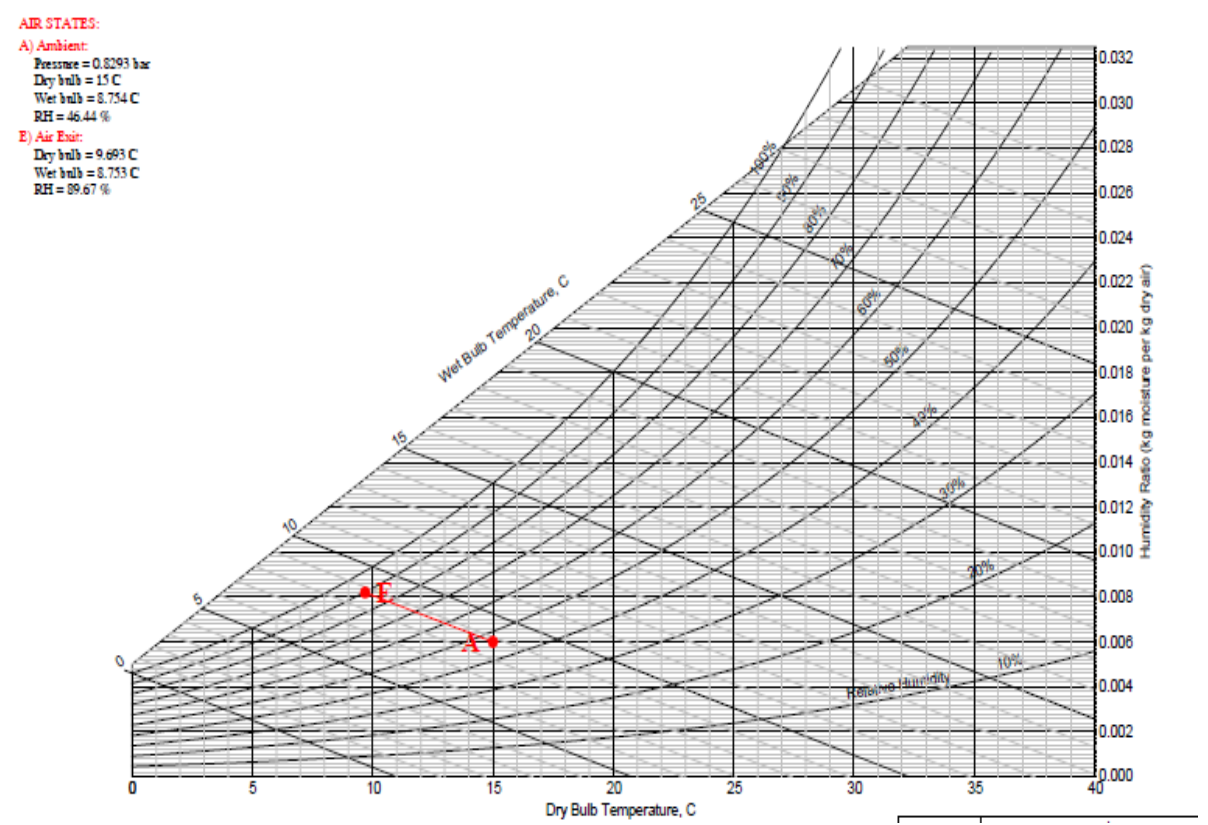

Figure 2. fogging system specifications

\subsection{Apply Compression Refrigeration Method}

A 5 degree reduction in temperature and 43 percent increasing humidity system is used to apply Compression refrigeration method in two case of Air cooled electric chiller and Water cooled electric chiller[9] by simulation software. This is shown in figure 3 and 4.

Flow rate and temperature of inlet and outlet water of system and pumps specification is shown.

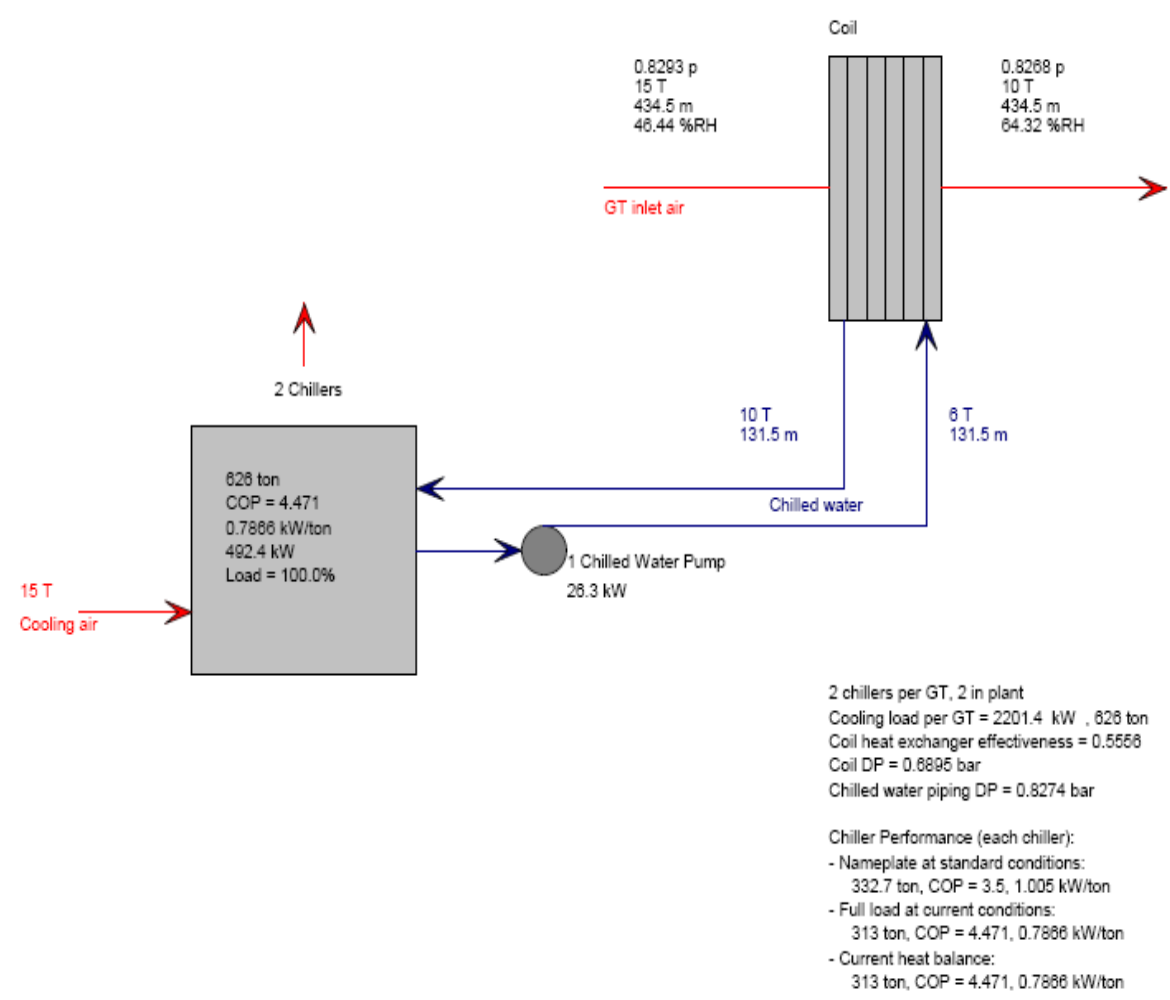

Figure 3. Air cooled Compression refrigeration system specification 


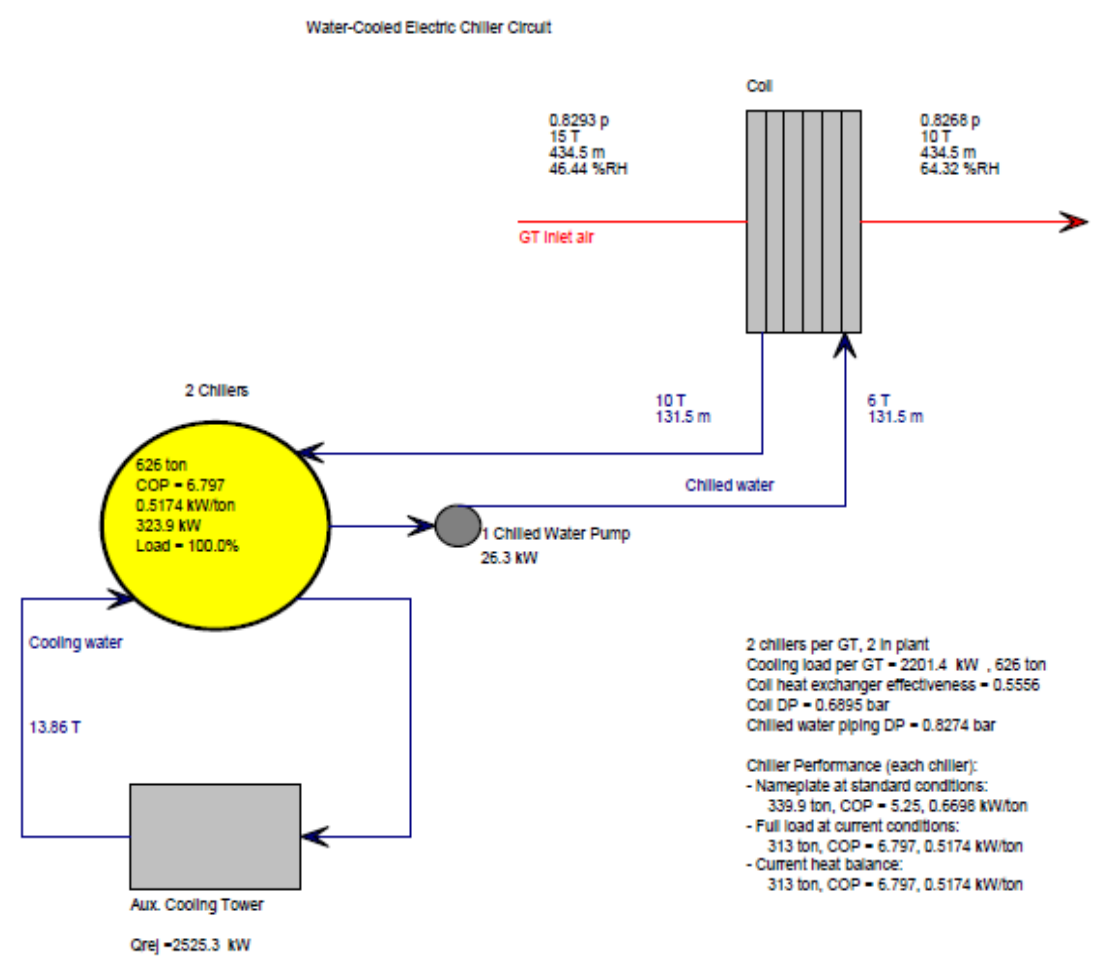

Figure 4. Air cooled Compression refrigeration system specifications

\subsection{Apply Absorption Chiller Method}

A 5 degree reduction in temperature and 43 percent increasing humidity system is used to apply absorption chiller method in two case of Single stage water cooled absorption chiller and two stage water cooled absorption chiller by simulation software. This is shown in figure 5 and 6.

Flow rate and temperature of inlet and outlet water of system and pumps specification is shown.

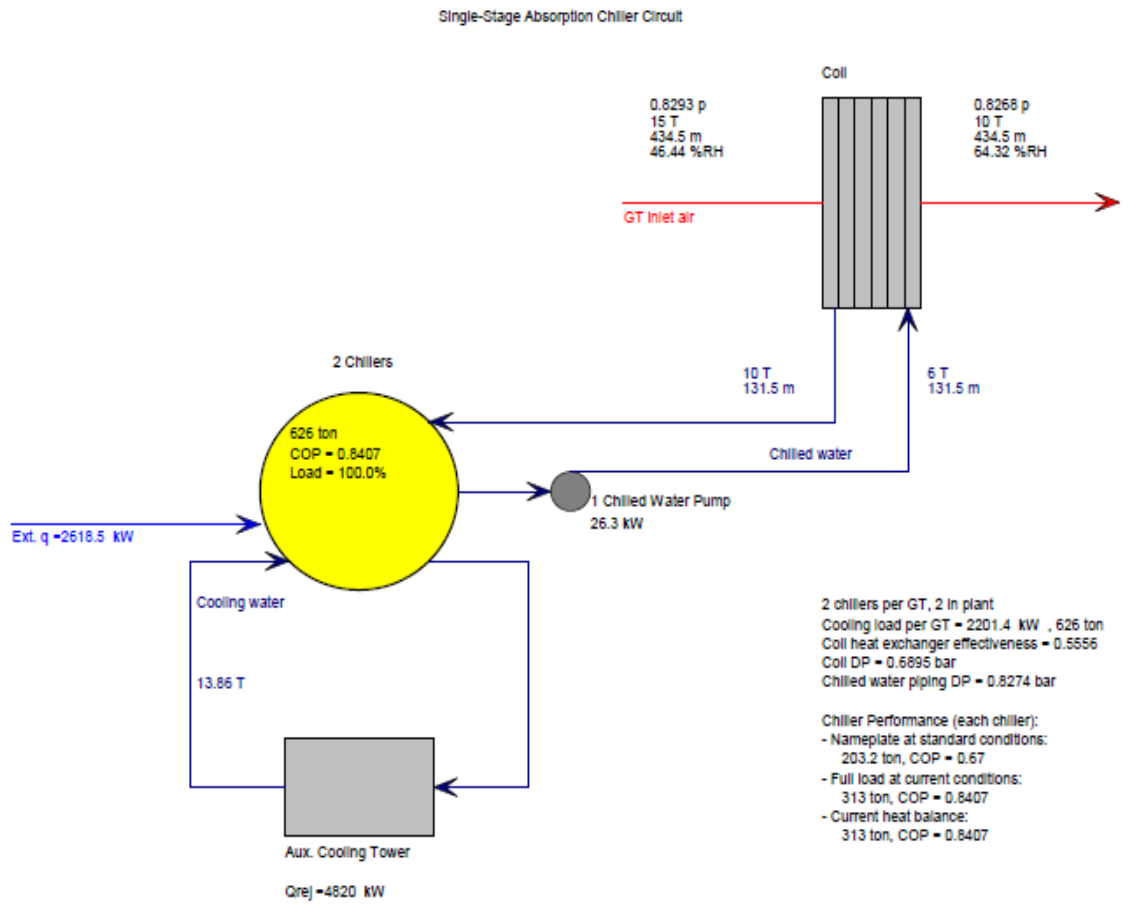

Figure 5. Single stage water cooled absorption chiller 


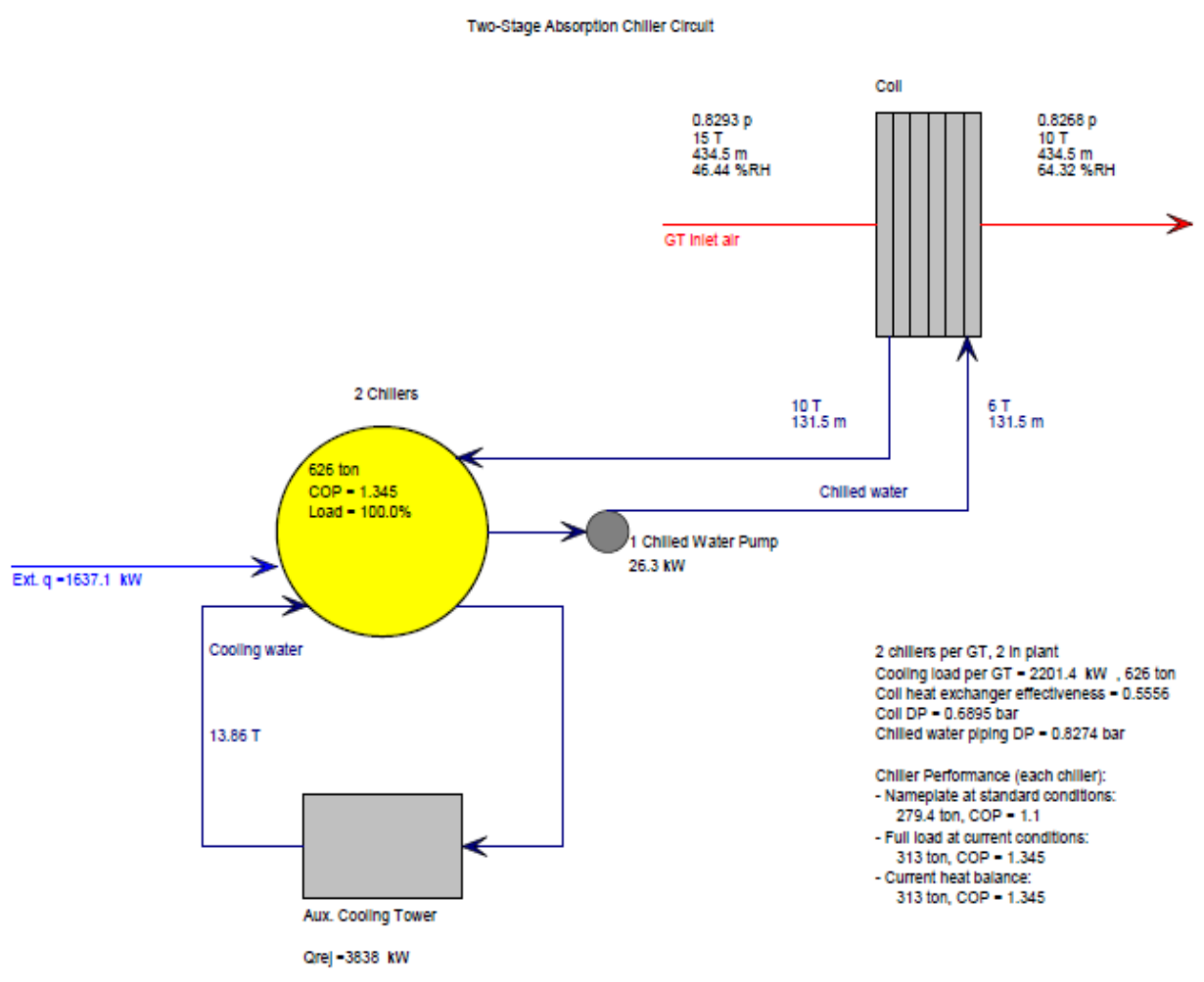

Figure 6. Two stage water cooled absorption chiller

\section{Apply Different Method of Efficiency Improvement in Khoramshahr Power Plant.}

\subsection{Apply Evaporative Cooling Method [7,8]}

A 5 degree reduction in temperature and 43 percent increasing humidity system is used to apply evaporative cooling method by simulation software. This is shown in figure 7 .

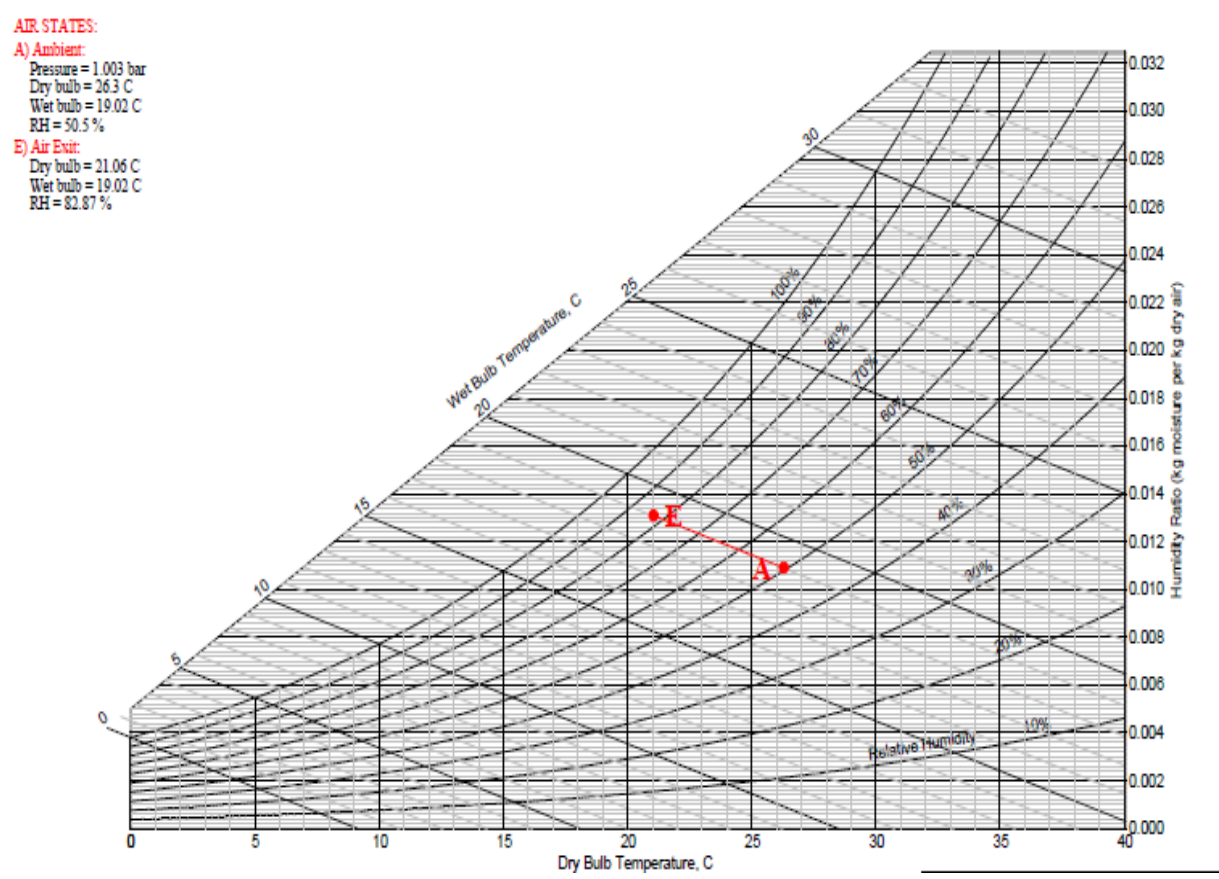

Figure 7. Evaporative cooling system specifications 


\subsection{Apply Fogging Method}

A 5 degree reduction in temperature and 43 percent increasing humidity system is used to apply fogging method by simulation software,. This is shown in figure 8.

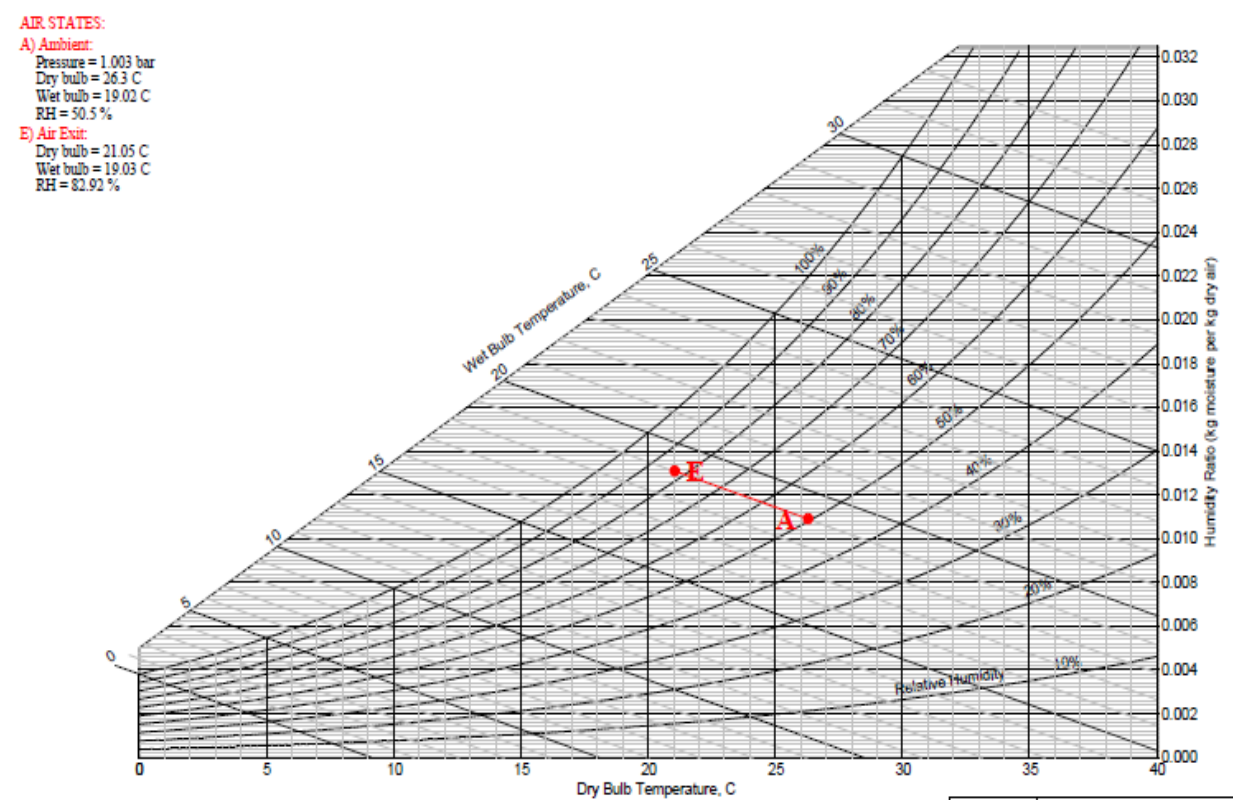

Figure 8. fogging system specifications

\subsection{Apply Compression Refrigeration Method.}

A 5 degree reduction in temperature and 43 percent increasing humidity system is used to apply Compression refrigeration method in two case of Air cooled electric chiller and Water cooled electric chiller by simulation software. This is shown in figure 9 and 10. Flow rate and temperature of inlet and outlet water of system and pumps specification is shown.

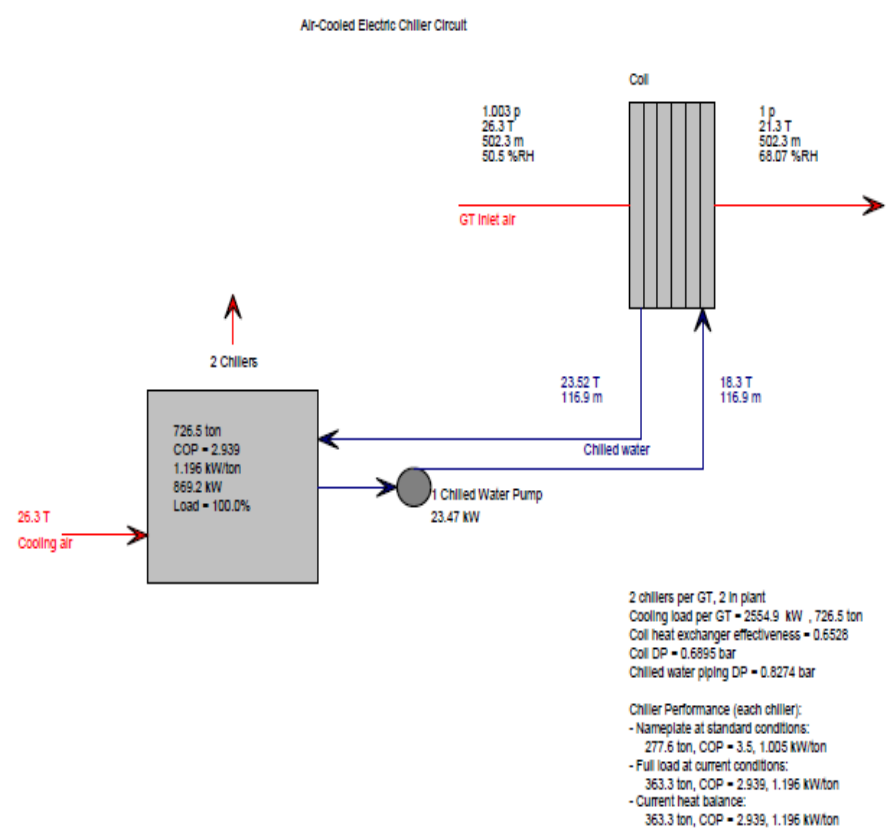

Figure 9. Air cooled Compression refrigeration system specification 


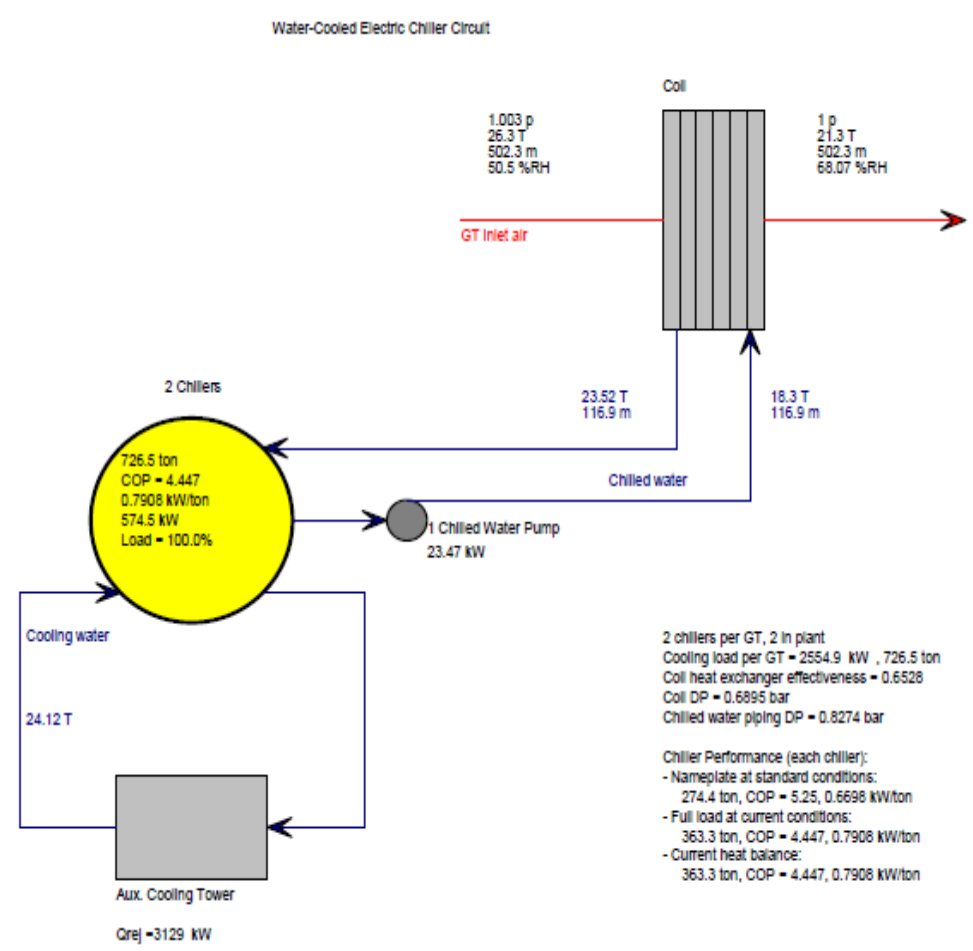

Figure 10. water cooled Compression refrigeration system specifications

\subsection{Apply Absorption Chiller Method}

A 5 degree reduction in temperature and 43 percent increasing humidity system is used to apply absorption chiller method in two case of Single stage water cooled absorption chiller and two stage water cooled absorption chiller by simulation software. This is shown in figure 11 and 12.

Flow rate and temperature of inlet and outlet water of system and pumps specification is shown.

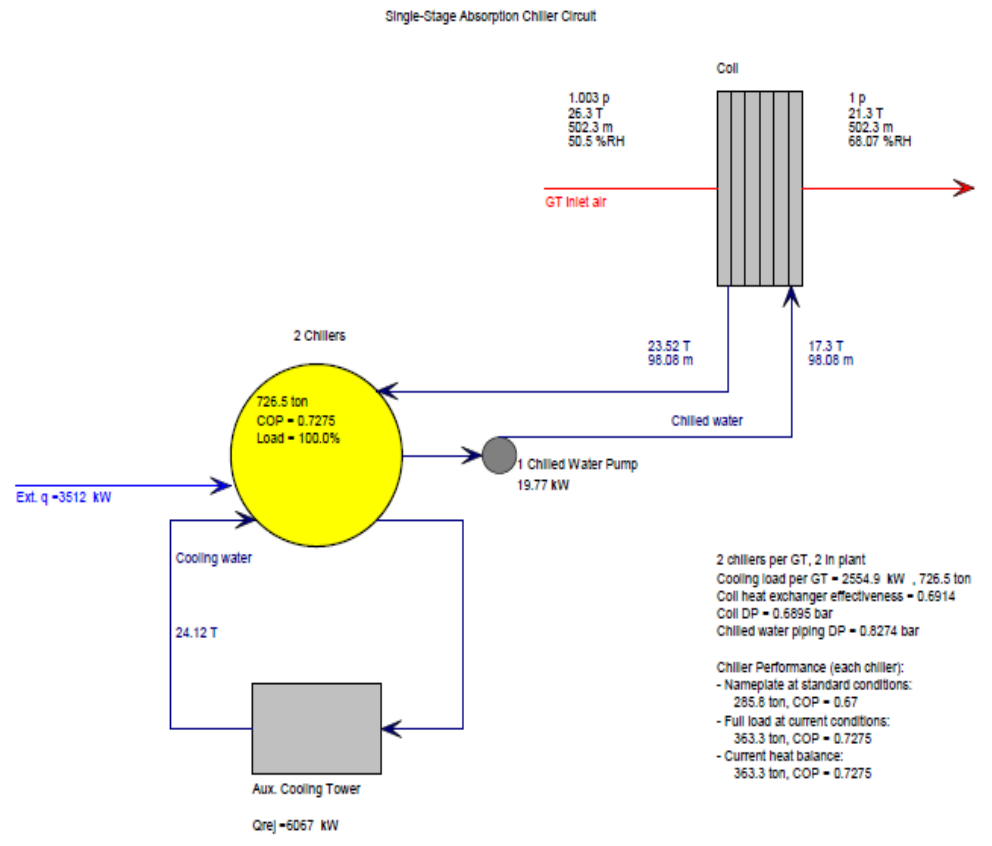

Figure 11. Single stage water cooled absorption chiller 


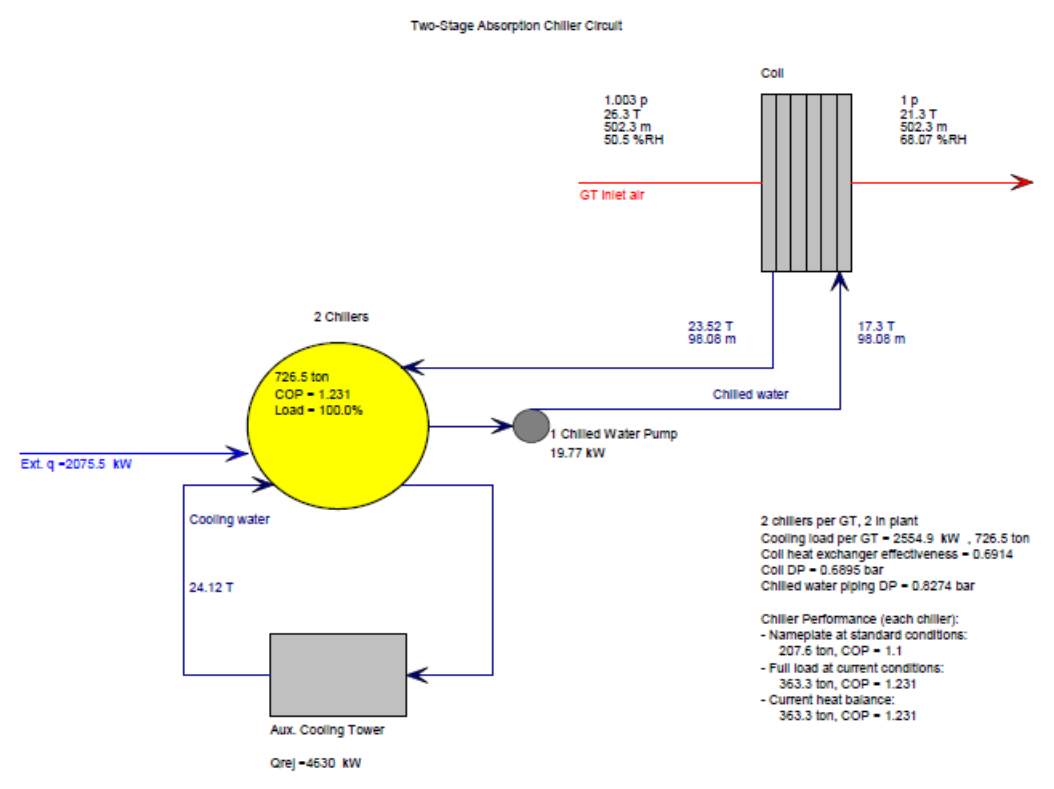

Figure 12. Two stage water cooled absorption chiller

\section{Different Method of Efficiency Improvement Analysis on Pilot Turbine Using Thermo Flow and GT Pro Software and Exploit Heat Balance of Each Method.}

Version 19 of Thermo flow software, produced in 2009 has been used to analyzing efficiency improvement methods. As mentioned before, to analyze efficiency improvement method using Thermo flow software, three different methods of evaporation, fog spray and compression and absorption refrigeration (which are divided into four methods) were selected. Also for better Comparison of methods for improving the efficiency and effects of environmental factors on turbine outlet, two V94.2 turbine already installed sites is selected. In the following, we present and analyze methods. Furthermore, in order to better analyze the results, applied conditions on efficiency improvement systems for both sites is considered as same.

\subsection{Basic Case}

Considering environmental condition of Sanadaj power plant, simulation is performed by simulation software [7, 10, 11]. This is shown in figure 13. Also result of simulation and heat balance is presented in table 1.

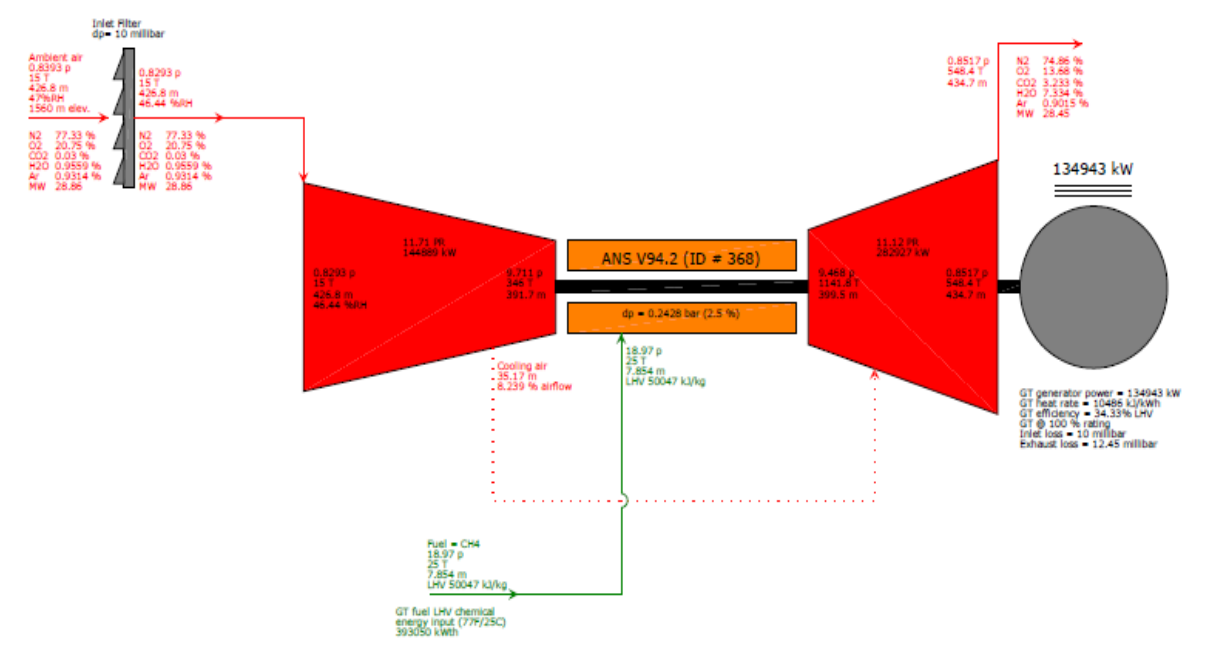

Gross Power $=134943 \mathrm{~kW}$, Aux, \& Transformer losses $=1601.6 \mathrm{~kW}$, Net Power Output $=133341 \mathrm{~kW}$
Gross Heat Rate $=10486 \mathrm{~kJ} / \mathrm{kWh}$, Net Heat Rate $=10612 \mathrm{~kJ} / \mathrm{kWh}(\mathrm{HWW})$ Gross Elec Eff $=34.33 \%$, Net Elec Eff Heat $33.92 \%$, PURPA Eff $=33.92 \%$, CHP (Total) Eff $=33.92 \%$ (LHV)
Fuel LHV chemical energy input $=393050 \mathrm{~kW}$

Figure 13. software output of Sanadaj power plant in basic case 
Table 1. software output of Sanadaj power plant in evaporative cooling method

\begin{tabular}{|c|c|c|c|}
\hline Heat Rate $(\mathrm{kJ} / \mathrm{kWh})$ & Efficiency & Power $(\mathrm{MW})$ & \\
\hline 10486 & 34.33 & 134.9 & Basic case \\
\hline
\end{tabular}

\subsection{Using Evaporative Cooling}

In next step, evaporative cooling is used and simulated by simulation software. This is shown in figure 14. Also result of simulation and heat balance is presented in table 2 .
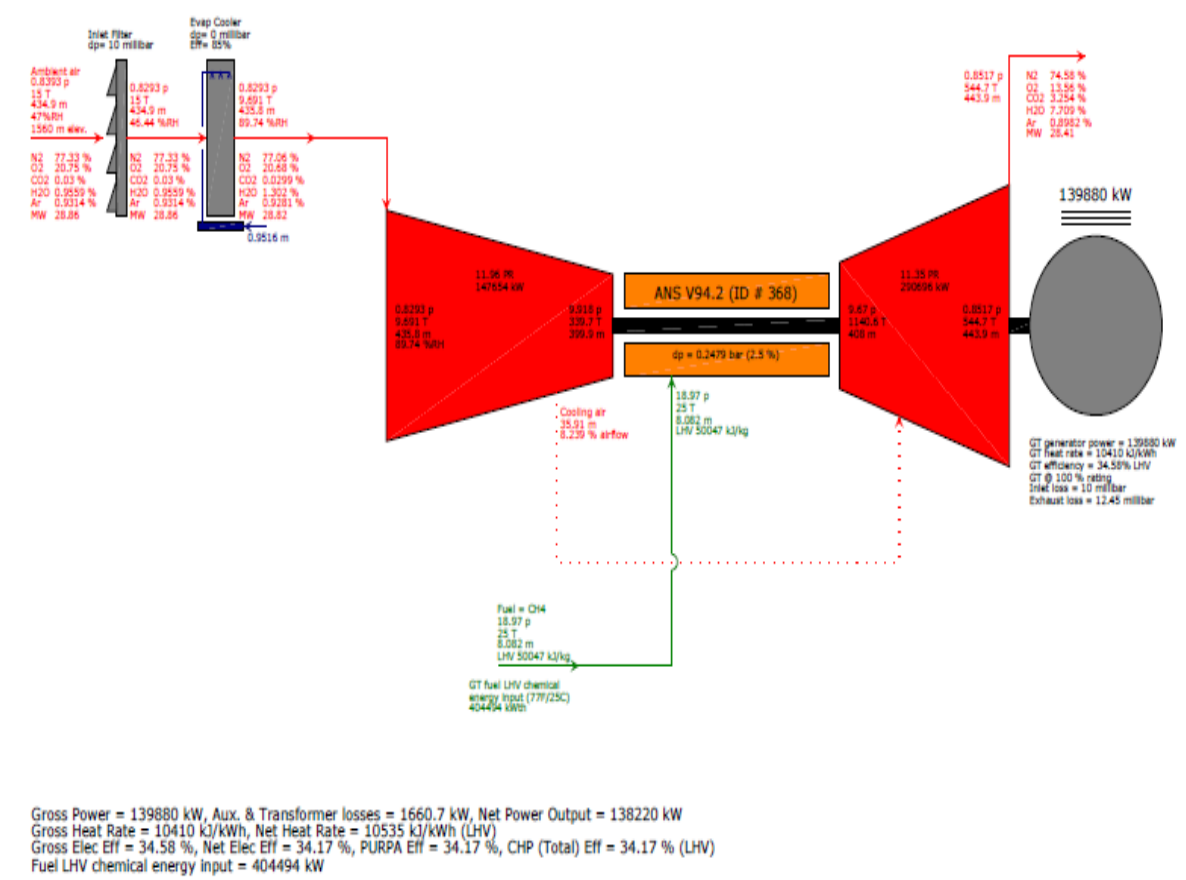

Figure 14. software output of Sanadaj power plant in evaporative cooling method

Table 2. software output of Sanadaj power plant in evaporative cooling method

\begin{tabular}{|c|c|c|c|}
\hline Heat Rate(kJ/kWh) & Efficiency & Power (MW) & \\
\hline 10410 & 34.58 & 139.9 & evaporative cooling method \\
\hline
\end{tabular}

In this case, compressor inlet temperature is $9.69 \mathrm{C}$, relative humidity is $89.74 \%$ and Flow rate of inlet air is $435.8 \mathrm{~kg}$. that rather than basic case with power of $134.9 \mathrm{~W}$, efficiency $34.33 \%$, compressor inlet temperature $15 \mathrm{C}$, relative humidity $43.3 \%$ and inlet air Flow rate $426.8 \mathrm{~kg}$ this result is produced, Increasing in power $5 \mathrm{MW}$, efficiency $0.25 \%$, relative humidity $43.3 \%$ and inlet air Flow rate $9 \mathrm{~kg}$ and reducing in compressor inlet temperature $5.31 \mathrm{C}$.

\subsection{Using Fogging Method}

In next step, fogging method is used and simulated by simulation software. This is shown in figure 15. Also result of simulation and heat balance is presented in table 3 . 


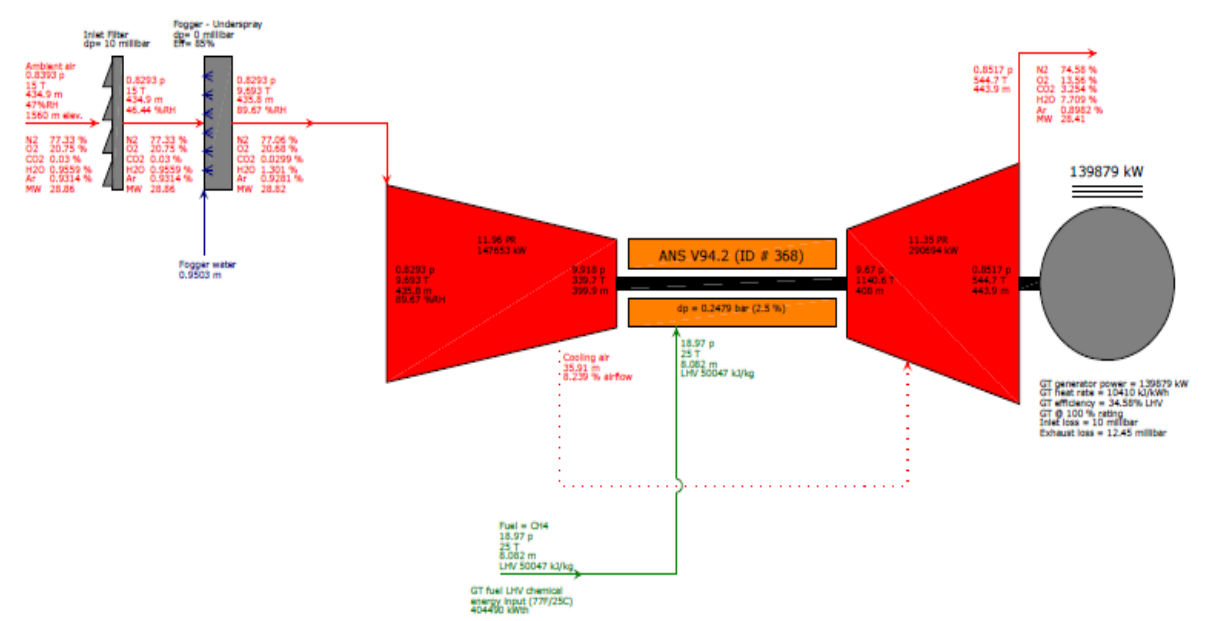

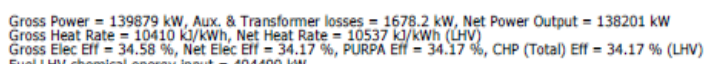

Figure15. software output of Sanadaj power plant by fogging mthod

Table 3. software output of Sanadaj power plant in fogging method

\begin{tabular}{|c|c|c|c|}
\hline Heat Rate(kJ/kWh) & Efficiency & Power (MW) & \\
\hline 10410 & 34.58 & 139.9 & fogging method \\
\hline
\end{tabular}

In this case, compressor inlet temperature is $9.69 \mathrm{C}$, relative humidity is $89.74 \%$ and Flow rate of inlet air is $435.8 \mathrm{~kg}$. that rather than basic case with power of $134.9 \mathrm{~W}$, efficiency $34.33 \%$, compressor inlet temperature $15 \mathrm{C}$, relative humidity $43.3 \%$ and inlet air Flow rate $426.8 \mathrm{~kg}$ this result is produced, Increasing in power $5 \mathrm{MW}$, efficiency $0.25 \%$, relative humidity $43.3 \%$ and inlet air Flow rate $9 \mathrm{~kg}$ and reducing in compressor inlet temperature $5.31 \mathrm{C}$.

\subsection{Using Compression Refrigeration Method}

In next step, Compression refrigeration method in two case of Air cooled electric chiller and Water cooled electric chiller is used and simulated by simulation software. This is shown in figure 16 and 17. Also result of simulation and heat balance is presented in table 4 and 5 .

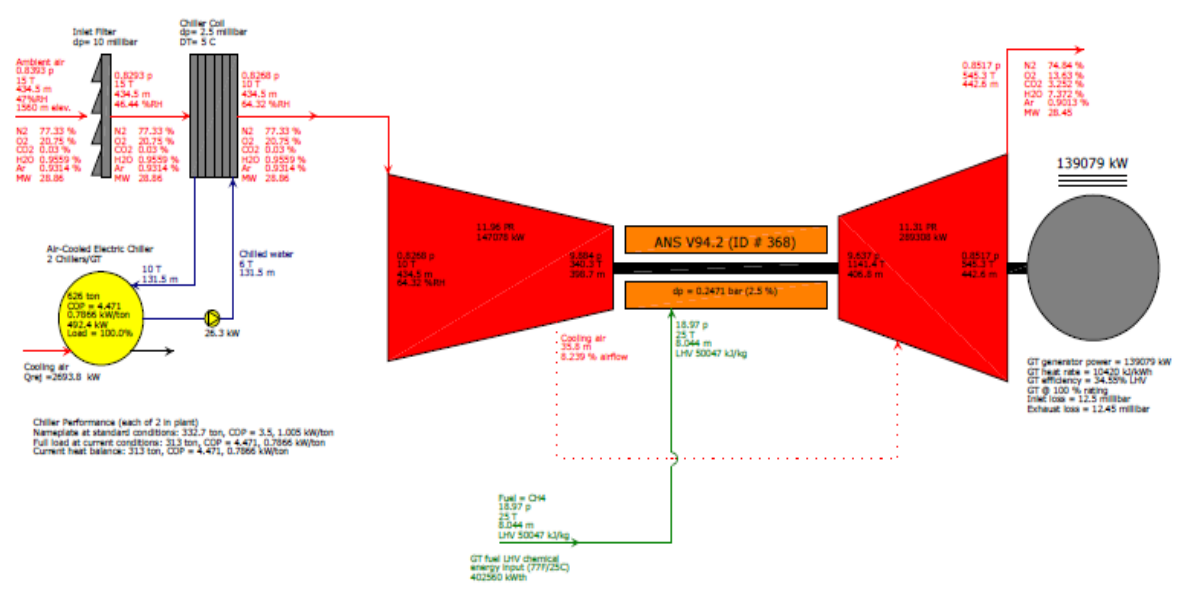

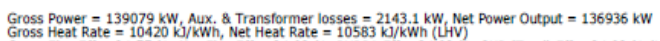

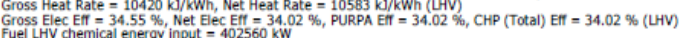

Figure 16. software output of Sanadaj power plant by Air cooled Compression refrigeration method 


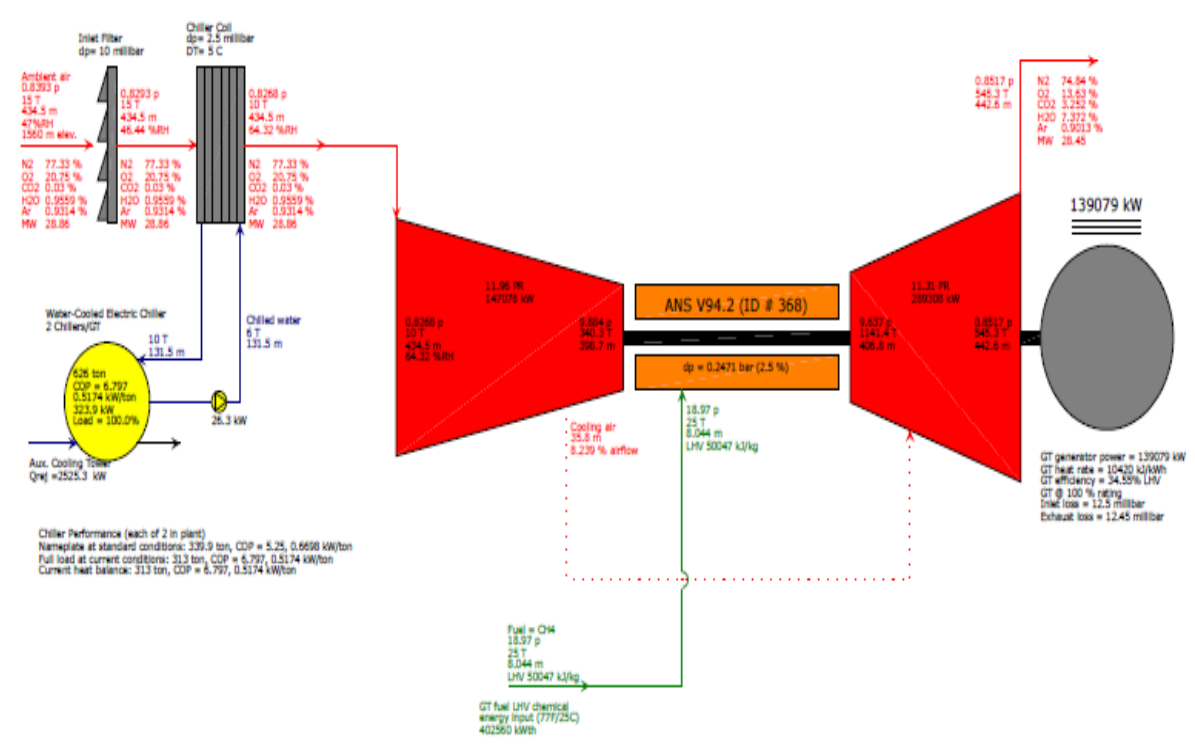

Gross Power $=139079 \mathrm{~kW}$, Aux. \& Transformer losses $=2037.5 \mathrm{~kW}$, Net Power Output $=137042 \mathrm{~kW}$ Gross Heat Rate $=10420 \mathrm{k} / \mathrm{kWh}$, Net Heat Rate $=10575 \mathrm{~kJ} / \mathrm{kWh}$ (LHV)
Gross Elec Eff $=34.55 \%$, Net Elec Eff $=34.04 \%$, PURPA Eff $=34.04 \%$, CHP (Total) EIf $=34.04 \%$ (LHV)
Fuel LHV chemical energy input $=402560 \mathrm{~kW}$

Figure 17. software output of Sanadaj power plant by air cooled Compression refrigeration method

Table 4. software output of Sanadaj power plant by air cooled Compression refrigeration method

\begin{tabular}{|c|c|c|c|}
\hline Heat Rate(kJ/kWh) & Efficiency & Power (MW) & \\
\hline 10420 & 34.55 & 139.1 & $\begin{array}{c}\text { air cooled Compression refrigeration } \\
\text { method }\end{array}$ \\
\hline
\end{tabular}

Table 5. software output of Sanadaj power plant by two stage water cooled absorption chiller method

\begin{tabular}{|c|c|c|c|}
\hline Heat Rate(kJ/kWh) & Efficiency & Power (MW) & \\
\hline 10420 & 34.55 & 139.1 & $\begin{array}{c}\text { two stage water cooled absorption chiller } \\
\text { method }\end{array}$ \\
\hline
\end{tabular}

In this case, compressor inlet temperature is $9.69 \mathrm{C}$, relative humidity is 89.74 and Flow rate of inlet air is $435.8 \mathrm{~kg}$. that rather than basic case with power of $134.9 \mathrm{~W}$, efficiency $34.33 \%$, compressor inlet temperature $15 \mathrm{C}$, relative humidity $43.3 \%$ and inlet air Flow rate $426.8 \mathrm{~kg}$ this result is produced. Increasing in power $5 \mathrm{MW}$, efficiency $0.25 \%$, relative humidity $43.3 \%$ and inlet air Flow rate $9 \mathrm{~kg}$ and reducing in compressor inlet temperature $5.31 \mathrm{C}$.

In this case, compressor inlet temperature is $10 \mathrm{C}$, relative humidity is $64.32 \%$ and Flow rate of inlet air is $434.5 \mathrm{~kg}$. that rather than basic case with power of $134.9 \mathrm{~W}$, efficiency $34.33 \%$, compressor inlet temperature $15 \mathrm{C}$, relative humidity $43.3 \%$ and inlet air Flow rate $426.8 \mathrm{~kg}$ this result is produced, Increasing in power $4.2 \mathrm{MW}$, efficiency $0.22 \%$, relative humidity $17.88 \%$ and no change in inlet air Flow rate and reducing in compressor inlet temperature $5 \mathrm{C}$.

\subsection{Using Absorption Chiller Method}

In next step, absorption chiller method in two case of Single stage water cooled absorption chiller and two stage water cooled absorption chiller is used and simulated by simulation software. This is shown in figure 18. Also result of simulation and heat balance is presented in table 6 . 


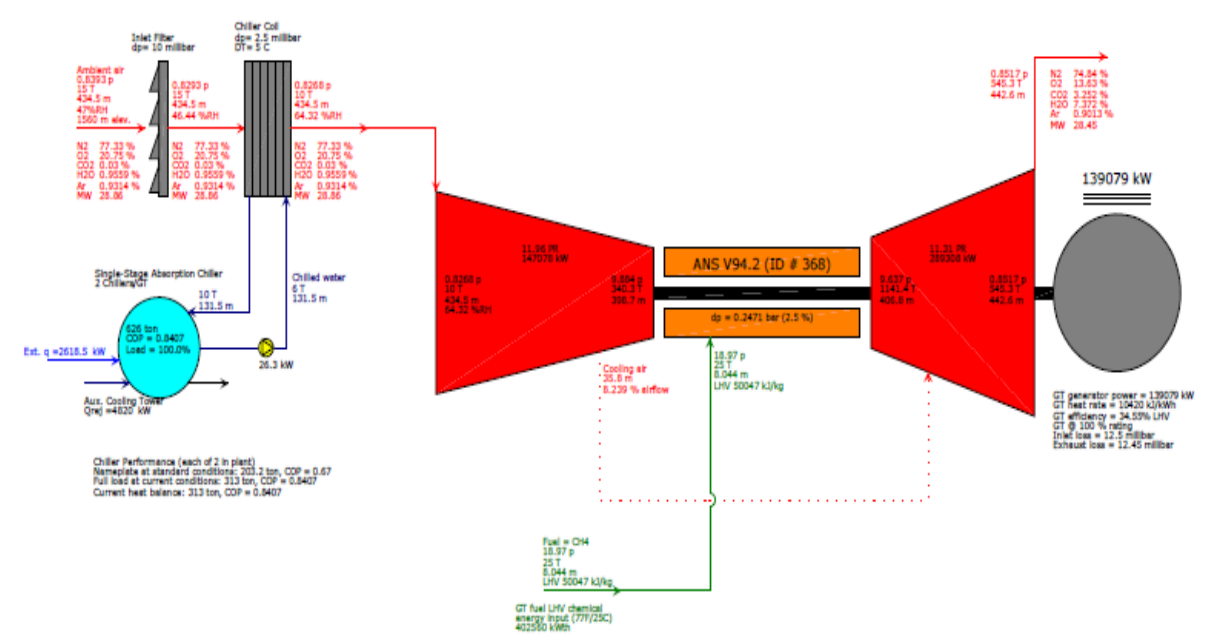

Gross Power $=139079 \mathrm{KW}$, Aux. \& Transformer losses $=1744.6 \mathrm{~kW}$, Net Power Output $=137335 \mathrm{~kW}$

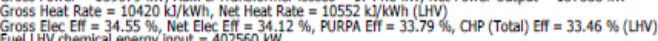

Figure 18. software output of Sanadaj power plant by two stage water cooled absorption chiller method

Table 6. software output of Sanadaj power plant by two stage water cooled absorption chiller method

\begin{tabular}{|c|c|c|c|}
\hline Heat Rate(kJ/kWh) & Efficiency & Power (MW) & \\
\hline 10420 & 34.55 & 139.1 & $\begin{array}{c}\text { single stage water cooled absorption chiller } \\
\text { method }\end{array}$ \\
\hline
\end{tabular}

In this case, compressor inlet temperature is $8 \mathrm{C}$, relative humidity is $73.64 \%$ and Flow rate of inlet air is $438.1 \mathrm{~kg}$. that rather than basic case with power of $134.9 \mathrm{~W}$, efficiency $34.33 \%$, compressor inlet temperature $15 \mathrm{C}$, relative humidity $43.3 \%$ and inlet air Flow rate $426.8 \mathrm{~kg}$, this result is produced, Increasing in power $4.2 \mathrm{MW}$, efficiency $0.22 \%$, relative humidity $17.88 \%$ and no change in inlet air Flow rate and reducing in compressor inlet temperature $5 \mathrm{C}$.

\section{Different Method of Efficiency Improvement Analysis in Khoramshahr Power Plant}

It should be mentioned, complete result of software and heat balance presented in appendix 3

\subsection{Basic Case}

At first, considering environmental condition of Sanadaj power plant, simulation is performed by simulation software. This is shown in figure 19. Also result of simulation and heat balance is presented in table 7. 


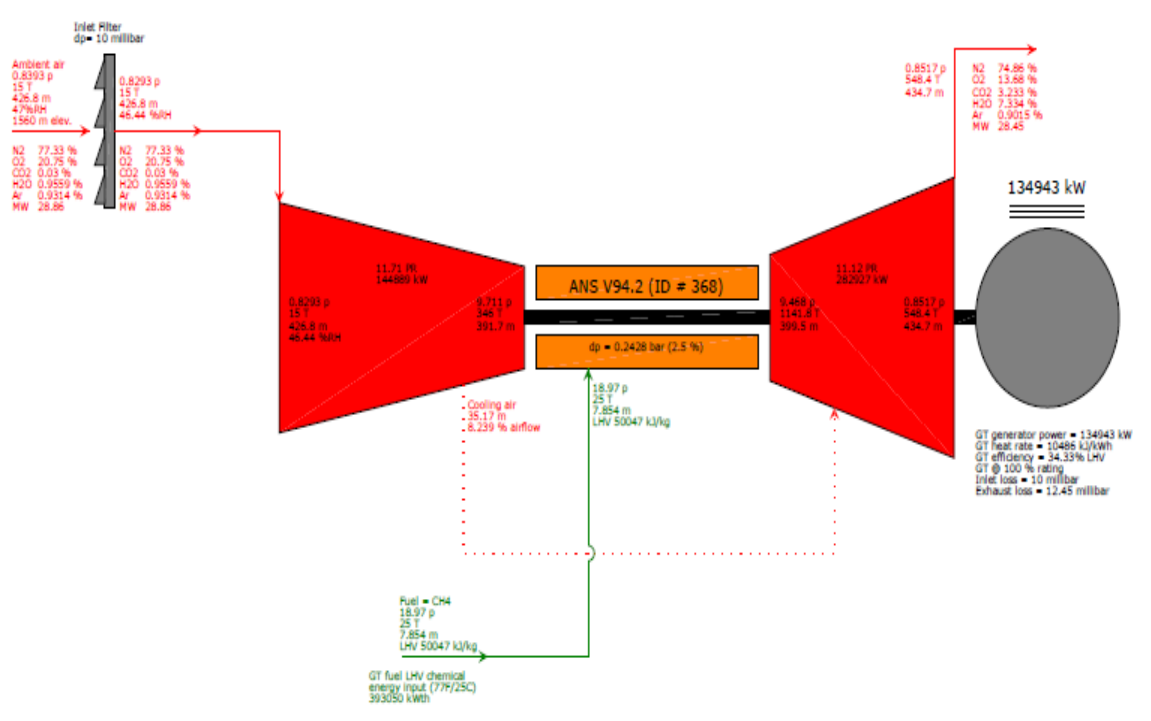

Gross Power $=134943 \mathrm{~kW}$, Aux, \& Transformer losses $=1601.6 \mathrm{~kW}$, Net Power Output $=133341 \mathrm{~kW}$
Gross Heat Rate $=10486 \mathrm{~kJ} / \mathrm{kWh}$, Net Heat Rate $=10612 \mathrm{~kJ} / \mathrm{kWh}($ LHV $)$

Gross Heat Rate $=10486 \mathrm{~kJ} / \mathrm{kWh}$, Net Heat Rate $=10612 \mathrm{~kJ} / \mathrm{kWh}$ (LHV)
Gross Elec Eff $=34.33 \%$, Net Elec Eff $=33.92 \%$, PURPA Eff $=33.92 \%, \mathrm{CHP}$ (Total) Eff $=33.92 \%$ (LHV)
Fuel LHV chemical energy input $=393050 \mathrm{~kW}$

Figure 19. software output of khoramshahr power plant in basic case

Table 7. software output of Khoramshahr power plant in evaporative cooling method

\begin{tabular}{|c|c|c|c|}
\hline Heat Rate $(\mathrm{kJ} / \mathrm{kWh})$ & Efficiency & Power $(\mathrm{MW})$ & \\
\hline 10652 & 33.8 & 152.3 & Basic case \\
\hline
\end{tabular}

In this case, compressor inlet temperature is $26.3 \mathrm{C}$, relative humidity is $50.5 \%$ and Flow rate of inlet air is $495.1 \mathrm{~kg}$

\subsection{Using evaporative cooling}

In next step, evaporative cooling is used and simulated by simulation software. This is shown in figure 20. Also result of simulation and heat balance is presented in table 8 .

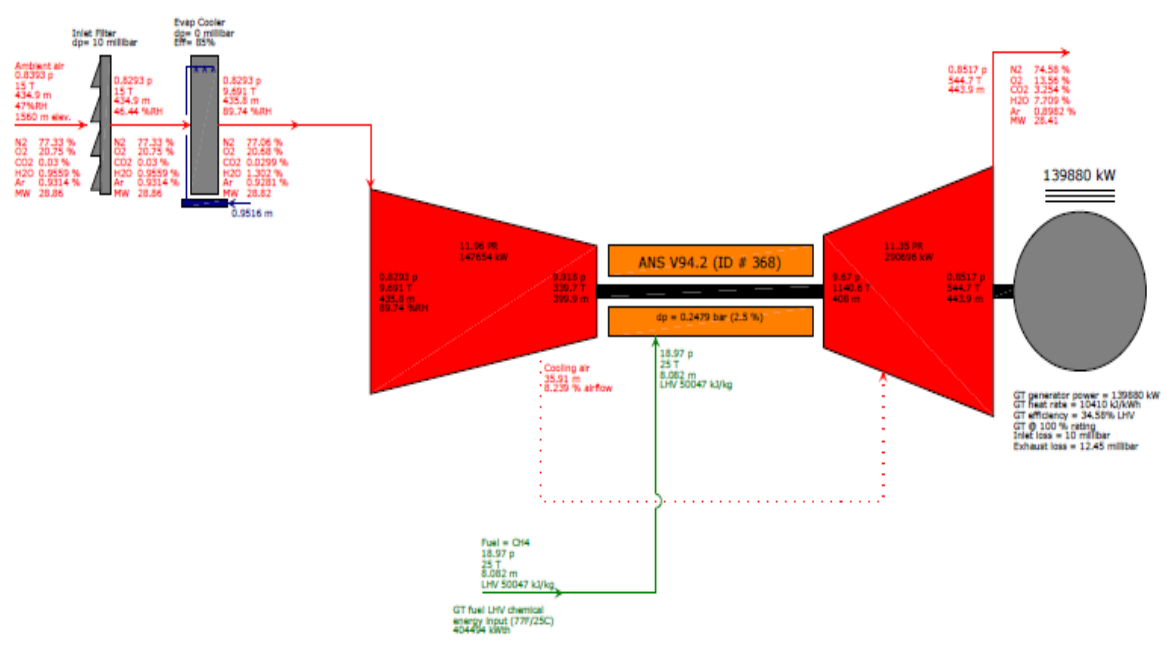

Gross Power $=139880 \mathrm{~kW}$, Aux. \& Transtormer losses $=1660.7 \mathrm{~kW}$, Net Power Output $=138220 \mathrm{~kW}$

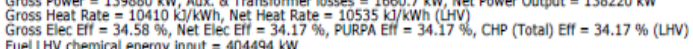

Figure 20. software output of khoramshahr power plant in evaporative cooling method 
Table 8. software output of Khoramshahr power plant in evaporative cooling method

\begin{tabular}{|c|c|c|c|}
\hline Heat Rate(kJ/kWh) & Efficiency & Power (MW) & \\
\hline 10571 & 34.1 & 157.4 & Evaporative cooling method \\
\hline
\end{tabular}

In this case, compressor inlet temperature is $21.1 \mathrm{C}$, relative humidity is $82.9 \%$ and Flow rate of inlet air is $503.3 \mathrm{~kg}$. that rather than basic case with power of $152.3 \mathrm{~W}$, efficiency $33.8 \%$, compressor inlet temperature $26.3 \mathrm{C}$, relative humidity $50.5 \%$ and inlet air Flow rate $495.1 \mathrm{~kg}$ this result is produced, Increasing in power $5.1 \mathrm{MW}$, efficiency $0.3 \%$, relative humidity $32.4 \%$ and inlet air Flow rate $8.2 \mathrm{~kg}$ and reducing in compressor inlet temperature $5.2 \mathrm{C}$.

\subsection{Using Fogging method}

In next step, fogging method is used and simulated by simulation software. This is shown in figure 21. Also result of simulation and heat balance is presented in table 9 .

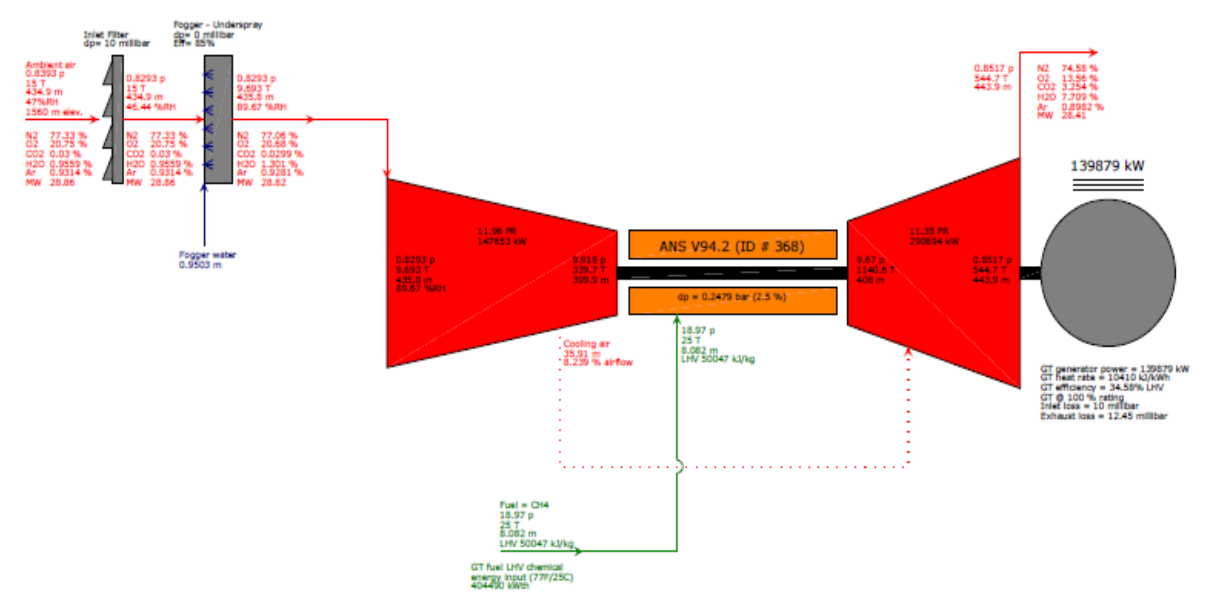

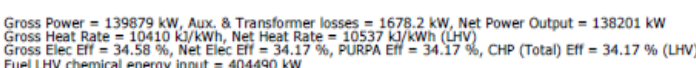

Figure 21. Software output of Khorams hahr power plant by fogging mthod

Table 9. software output of Khoramshahr power plant in fogging method

\begin{tabular}{|c|c|c|c|}
\hline Heat Rate $(\mathrm{kJ} / \mathrm{kWh})$ & Efficiency & Power (MW) & \\
\hline 10571 & 34.1 & 157.4 & Fogging method \\
\hline
\end{tabular}

In this case, compressor inlet temperature is $21.1 \mathrm{C}$, relative humidity is $82.9 \%$ and Flow rate of inlet air is $503.3 \mathrm{~kg}$. that rather than basic case with power of $152.3 \mathrm{~W}$, efficiency $33.8 \%$, compressor inlet temperature $26.3 \mathrm{C}$, relative humidity $50.5 \%$ and inlet air Flow rate $495.1 \mathrm{~kg}$ this result is produced, Increasing in power $5.1 \mathrm{MW}$, efficiency $0.3 \%$, relative humidity $32.4 \%$ and inlet air Flow rate $8.2 \mathrm{~kg}$ and reducing in compressor inlet temperature $5.2 \mathrm{C}$.

\subsection{Using Compression Refrigeration Method}

In next step, Compression refrigeration method in two case of Air cooled electric chiller and Water cooled electric chiller is used and simulated by simulation software. This is shown in figure 22. Also result of simulation and heat balance is presented in table 10 .

Table 10. software output of Khoramshahr power plant by air cooled Compression refrigeration method

\begin{tabular}{|c|c|c|c|}
\hline Heat Rate(kJ/kWh) & Efficiency & Power $(\mathrm{MW})$ & \\
\hline 10579 & 34.03 & 156.6 & $\begin{array}{c}\text { Air cooled Compression refrigeration } \\
\text { method }\end{array}$ \\
\hline
\end{tabular}


In this case compressor inlet temperature is $21.3 \mathrm{C}$, relative humidity is $68.07 \%$ and Flow rate of inlet air is $502.3 \mathrm{~kg}$. that rather than basic case with power of $152.3 \mathrm{~W}$, efficiency $33.8 \%$, compressor inlet temperature $26.3 \mathrm{C}$, relative humidity $50.5 \%$ and inlet air Flow rate $495.1 \mathrm{~kg}$ this result is produced. Increasing in power $4.3 \mathrm{MW}$, efficiency $0.23 \%$, relative humidity $17.57 \%$ and inlet air Flow rate $7.2 \mathrm{~kg}$ and reducing in compressor inlet temperature $5 \mathrm{C}$.

\subsection{Using Absorption Chiller Method}

In next step, absorption chiller method in two case of Single stage water cooled absorption chiller and two stage water cooled absorption chiller is used and simulated by simulation software. This is shown in figure 23 and 24. Also result of simulation and heat balance is presented in table 11 and 12 .

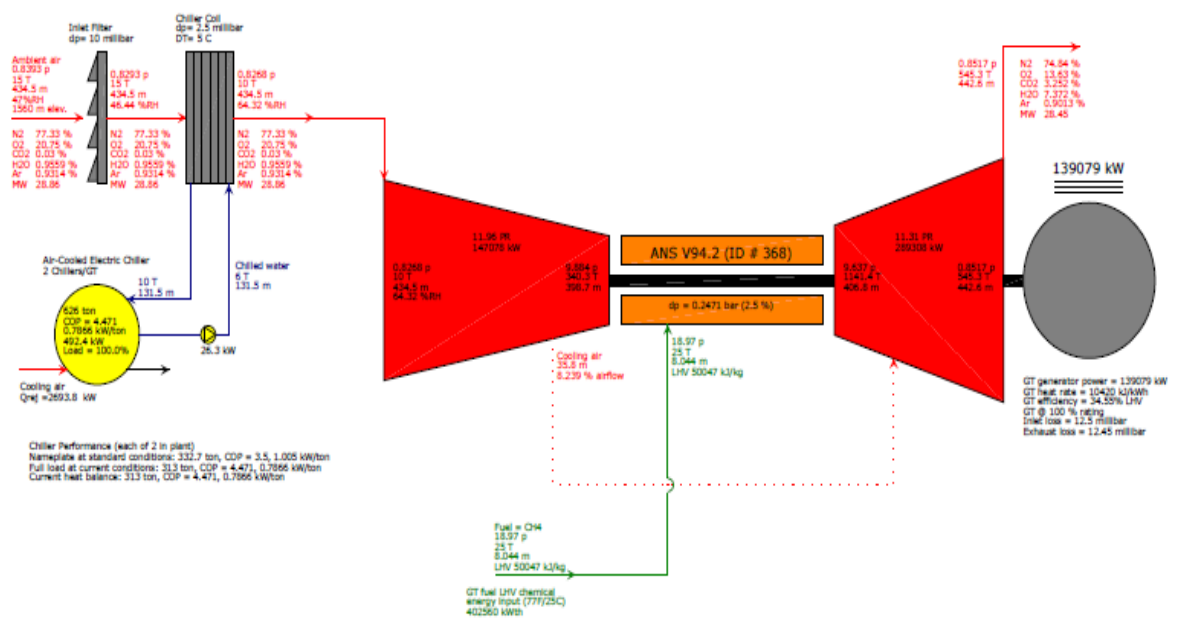

Gross Power $=139079 \mathrm{~kW}$, Aux. \& Transformer losses $=2143.1 \mathrm{~kW}$. Net Power Output $=136936 \mathrm{~kW}$
Gross

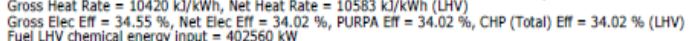

Figure 22. Software output of Khoramshahr power plant by Air cooled Compression refrigeration method

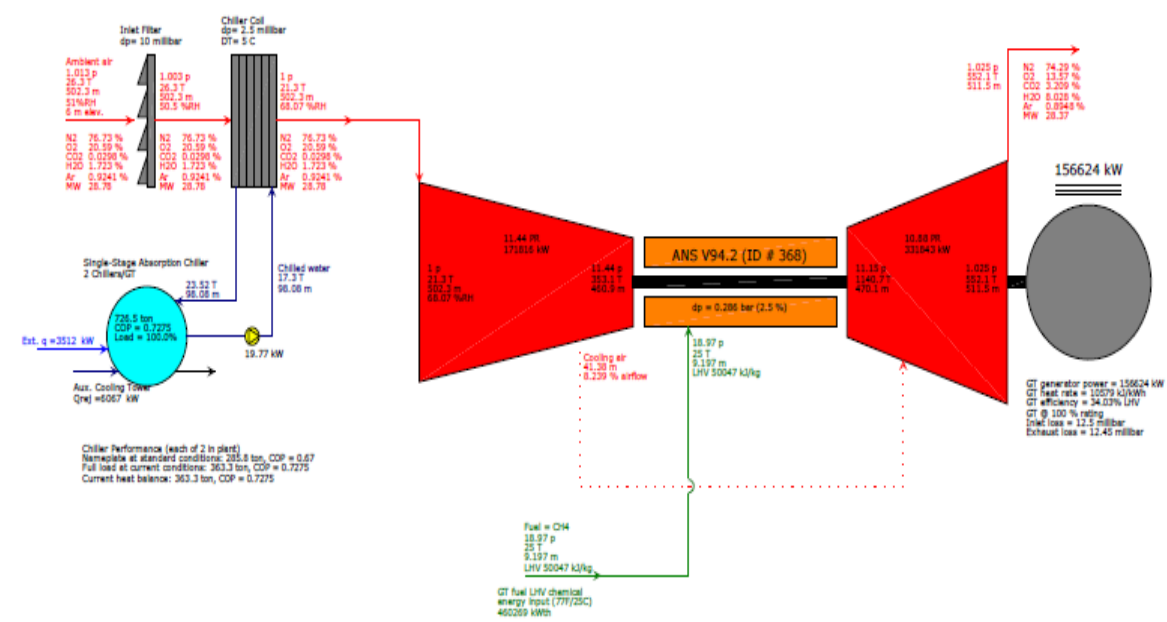

Gross Power $=156624 \mathrm{~kW}$, Aux. \& Transformer bosses $=1874.6 \mathrm{~kW}$, Net Power Output $=154749 \mathrm{~kW}$

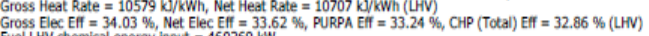

Figure23. software output of Khoramshahr power plant by single stage water cooled absorption chiller method 


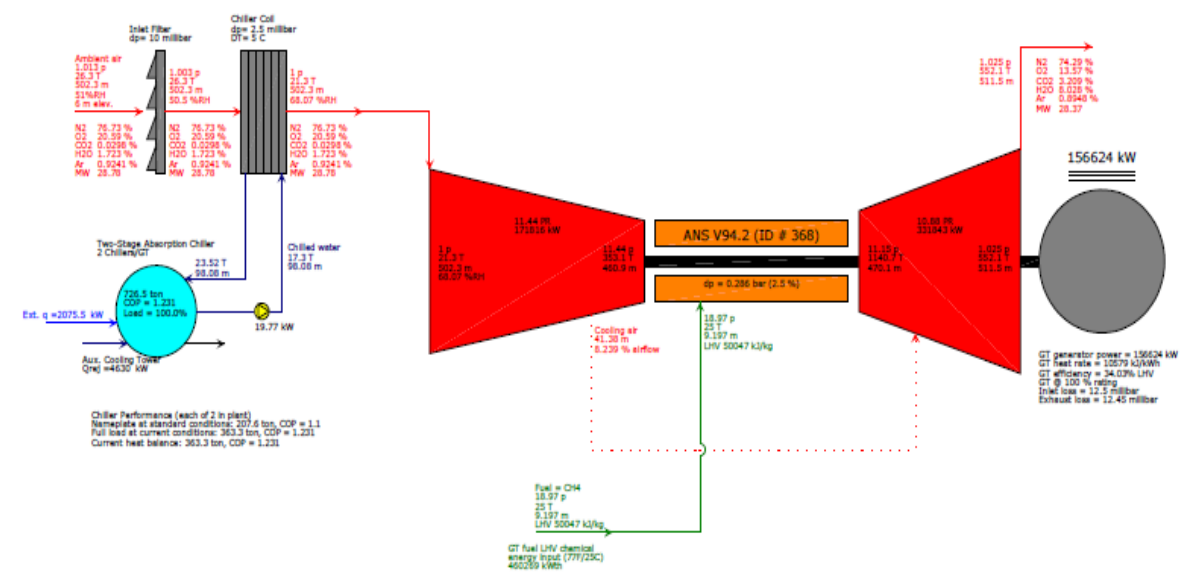

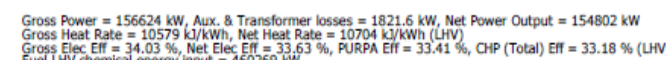

Figuure 24. software output of Khoramshahr power plant by two stage water cooled absorption chiller method

Table 11. software output of Khoramshahr power plant by single stage water cooled absorption chiller method

\begin{tabular}{|c|c|c|c|}
\hline Heat Rate $(\mathrm{kJ} / \mathrm{kWh})$ & Efficiency & Power (MW) & \\
\hline 10579 & 34.03 & 156.6 & $\begin{array}{c}\text { Single stage water cooled absorption chiller } \\
\text { method }\end{array}$ \\
\hline
\end{tabular}

Table 12. software output of Khoramshahr power plant by two stage water cooled absorption chiller method

\begin{tabular}{|c|c|c|c|}
\hline Heat Rate(kJ/kWh) & Efficiency & Power (MW) & \\
\hline 10579 & 34.03 & 156.6 & $\begin{array}{c}\text { Two stage water cooled absorption } \\
\text { chiller method }\end{array}$ \\
\hline
\end{tabular}

In this case compressor inlet temperature is $21.3 \mathrm{C}$, relative humidity is $68.07 \%$ and Flow rate of inlet air is $502.3 \mathrm{~kg}$. that rather than basic case with power of $152.3 \mathrm{~W}$, efficiency $33.8 \%$, compressor inlet temperature $26.3 \mathrm{C}$, relative humidity $50.5 \%$ and inlet air Flow rate $495.1 \mathrm{~kg}$ this result is produced. Increasing in power $4.3 \mathrm{MW}$, efficiency $0.23 \%$, relative humidity $17.57 \%$ and inlet air Flow rate $7.2 \mathrm{~kg}$ and reducing in compressor inlet temperature $5 \mathrm{C}$.

\section{Discussion and Conclusion}

Software result of Sanandaj power plant summarized in table 13

Table 13. Result of different efficiency method improvement in Sanadaj power plant

\begin{tabular}{|c|c|c|}
\hline Efficiency & Power (MW) & \\
\hline 34.33 & 134.9 & Basic case \\
\hline 34.58 & 139.9 & Fogging method \\
\hline 34.58 & 139.9 & Evaporative Cooling method \\
\hline 34.55 & 139.1 & Water cooled Compression refrigeration method \\
\hline 34.55 & 139.1 & Single stage water cooled absorption chiller method \\
\hline 34.55 & 139.1 & Two stage water cooled absorption chiller method \\
\hline 34.55 & 139.1 & \\
\hline
\end{tabular}




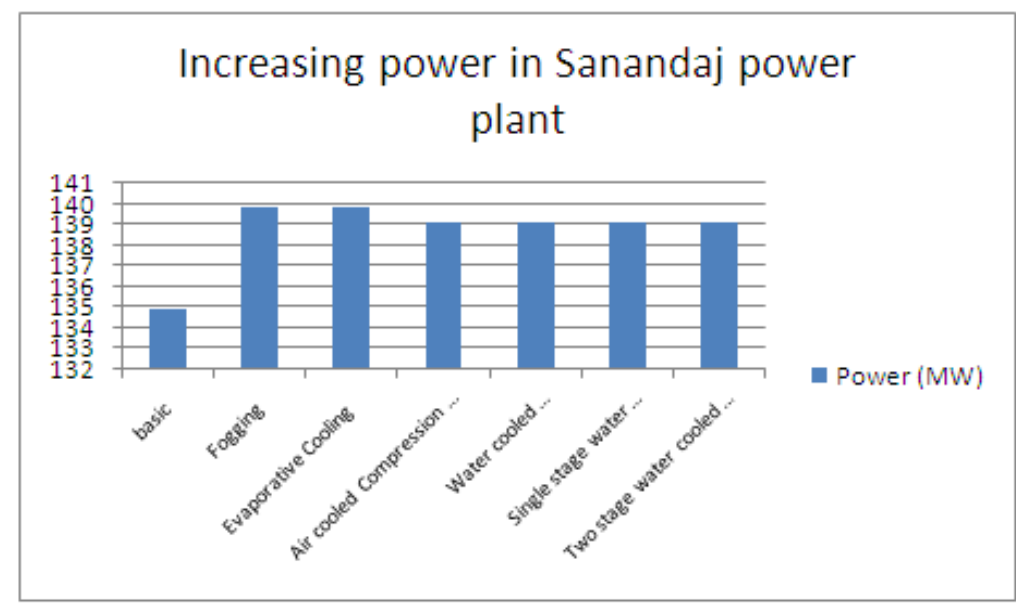

Chart 1. Increasing power of different systems in Sanandaj power plant.

According to table 13 and chart 1 it is observed that, using fogging and evaporative methods are most effective methods of efficiency improvement in Sanandaj power plant, that cause about 5MW increasing in efficiency. After that, compression refrigeration and absorption refrigeration methods with efficiency increasing about $4 \mathrm{MW}$ are in second place. However, at this stage, the economic evaluation methods not mentioned and the classification is done solely in terms of efficiency improvement.

Software result of Khoramshahr power plant summarized in table 14.

Table 14. Result of different efficiency method improvement in Khoramshahr power plant

\begin{tabular}{|c|c|c|}
\hline Efficiency & Power (MW) & \\
\hline 33.8 & 152.3 & Basic case \\
\hline 34.1 & 157.4 & Fogging method \\
\hline 34.1 & 157.4 & Evaporative Cooling method \\
\hline 34.03 & 156.6 & Water cooled Compression refrigeration method \\
\hline 34.03 & 156.6 & Single stage water cooled absorption chiller method \\
\hline 34.03 & 156.6 & Two stage water cooled absorption chiller method \\
\hline 34.03 & 156.6 & \\
\hline
\end{tabular}

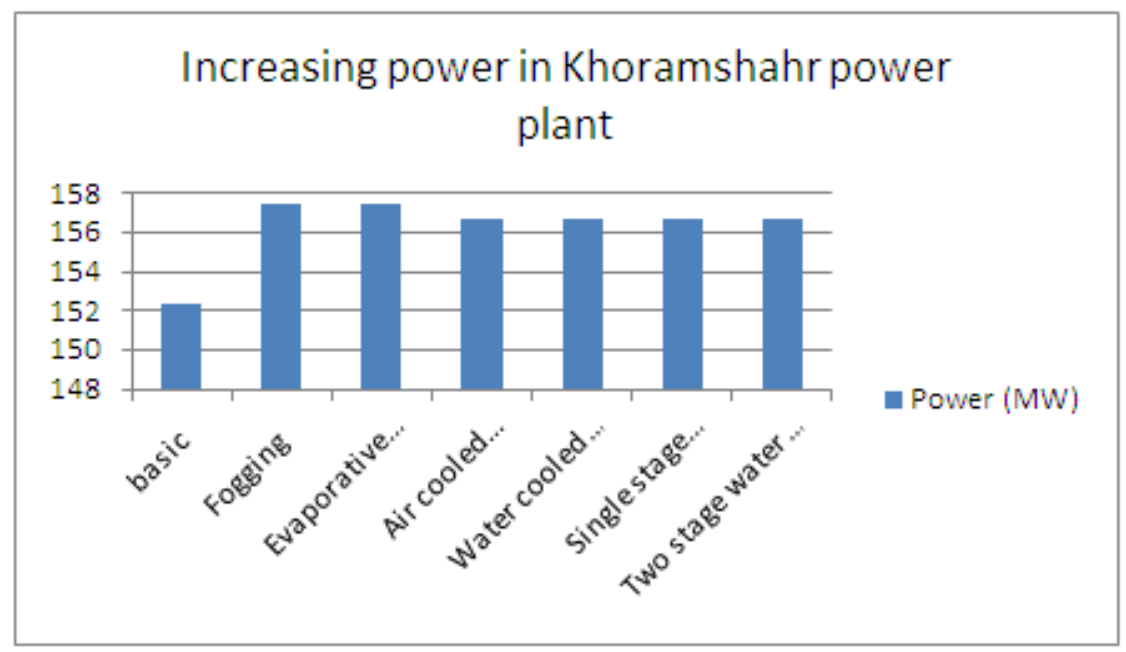

Chart 2. Increasing power of different systems in Khoramshahr power plant. 
According to table 14 and chart 2 it is observed that, using fogging and evaporative methods are most effective methods of efficiency improvement in Khoramshahr power plant, that cause about $6 \mathrm{MW}$ increasing in efficiency. After that, compression refrigeration and absorption refrigeration methods with efficiency increasing about 4MW are in second place. However, at this stage, the economic evaluation methods not mentioned and the classification is done solely in terms of efficiency improvement.

\subsection{Technical and economical analysis of different efficiency improvement methods in Sanandaj power plant $[12,13]$}

Calculation result of Sanandaj power plant construction and efficiency improvement systems installation, presented in table 15

Table 15. Calculation result of Sanandaj power plant construction and efficiency improvement systems installation

\begin{tabular}{|c|c|c|c|}
\hline Each KW cost (\$) & Efficiency & Power (MW) & \\
\hline 594 & 34.33 & 134.9 & Basic case \\
\hline 590 & 34.58 & 139.9 & Fogging method \\
\hline 592 & 34.58 & 139.9 & Evaporative Cooling method \\
\hline 598 & 34.55 & 139.1 & Water cooled Compression refrigeration method \\
\hline 600 & 34.55 & 139.1 & Single stage water cooled absorption chiller method \\
\hline 597 & 34.55 & 139.1 & Two stage water cooled absorption chiller method \\
\hline 599 & 34.55 & 139.1 & \\
\hline
\end{tabular}

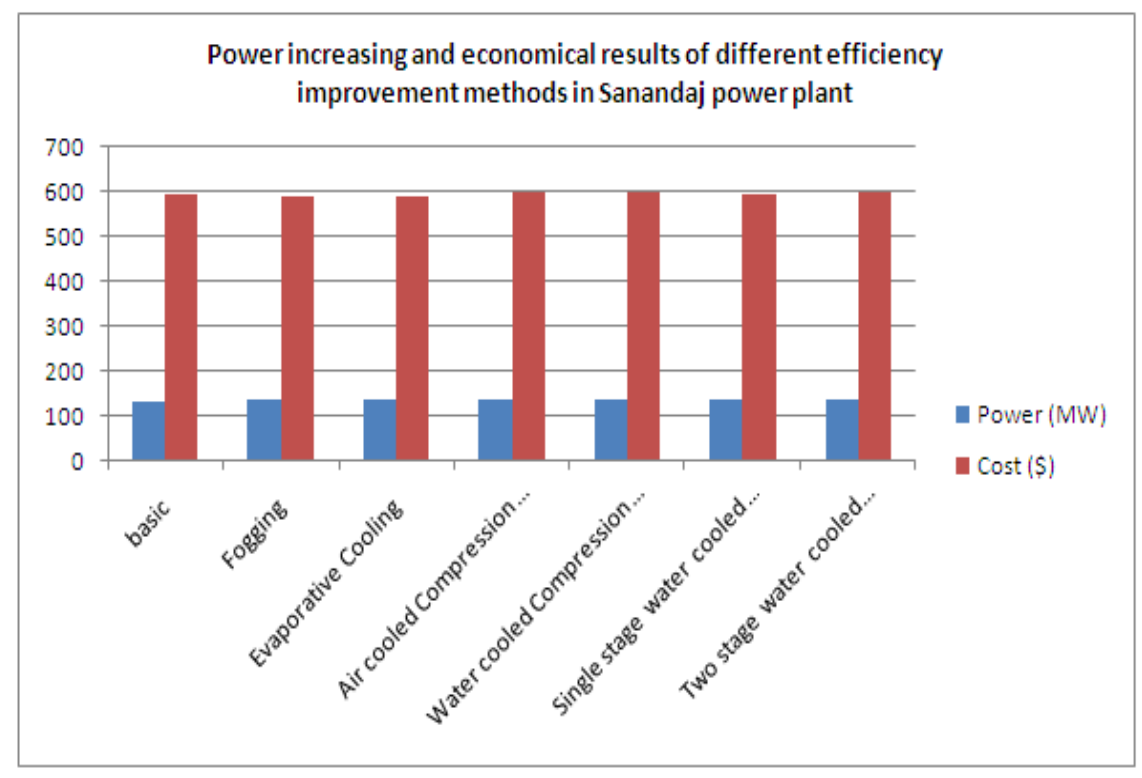

Chart. 3 power increasing and economical results of different efficiency improvement methods in Sanandaj power plant

According to Table 15 and chart 3 it is observed that, fogging method is most appropriate method in term of increasing power and construction coast per $\mathrm{KW}$, and next, evaporative cooling method is recommended.

After all it can be resulted, by using fogging method, outlet power of turbine is increased about $5 \mathrm{MW}$, however construction cost per $\mathrm{KW}$ reduced $4 \$$.

\subsection{Technical and Economical Analysis of Different Efficiency Improvement Methods in Khoramshahr Power Plant}

Calculation result of Khoramshahr power plant construction and efficiency improvement systems installation, presented in table 16 
Table 16. Calculation result of Khoramshahr power plant construction and efficiency improvement systems installation

\begin{tabular}{|c|c|c|c|}
\hline Each KW cost (\$) & Efficiency & Power (MW) & Basic case \\
\hline 528 & 33.8 & 152.3 & Fogging method \\
\hline 527 & 34.1 & 157.4 & Evaporative Cooling method \\
\hline 528 & 34.1 & 157.4 & Air cooled Compression refrigeration method \\
\hline 534 & 34.03 & 156.6 & Water cooled Compression refrigeration method \\
\hline 534 & 34.03 & 156.6 & Single stage water cooled absorption chiller method \\
\hline 534 & 34.03 & 156.6 & Two stage water cooled absorption chiller method \\
\hline 532 & 34.03 & 156.6 &
\end{tabular}

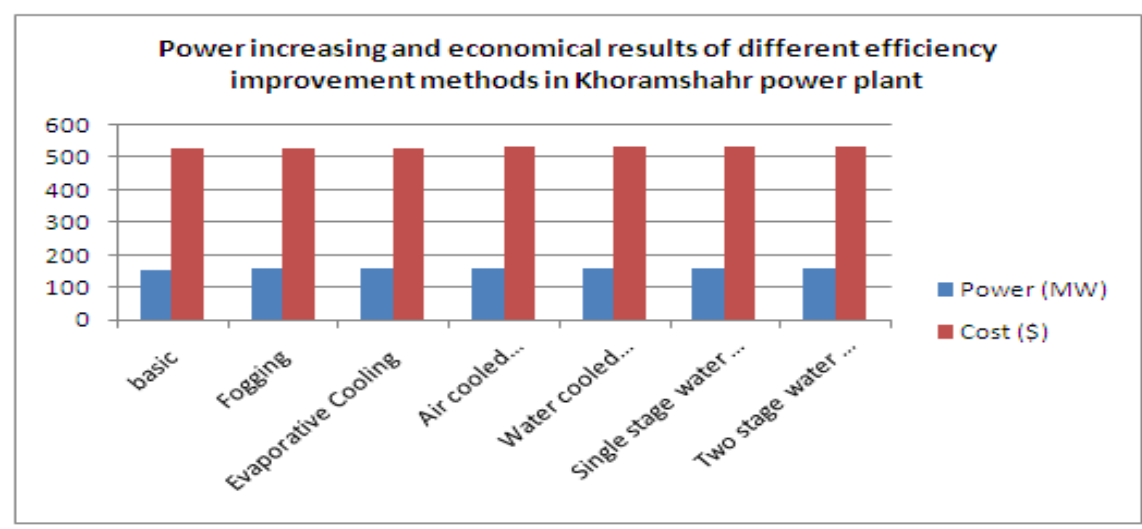

Chart 4. power increasing and economical results of different efficiency improvement methods in Khoramshahr power plant

According to Table 16 and chart 4 it is observed that, fogging method is most appropriate method in term of increasing power and construction coast per $\mathrm{KW}$, and next, evaporative cooling method is recommended.

After all it can be resulted, by using fogging method, outlet power of turbine is increased about $6 \mathrm{MW}$, however construction cost per KW reduced $4 \$$.

\section{REFRENCES}

[1] B. Omidvar, Gas Turbine Inlet Air Cooling, The 3rd Annual Australian Gasturbine Conference, 6th - 7th December 2001, Melbourne, Australia.

[2] Turbine Inlet Cooling Association (TICA) white paper, November 2009.

[3] E. Kakaras, A. Doukelis, S. Karellas, Compressor intake-air cooling in gasturbine plants, Journal of Energy, 29 (12-15), 2347-2358.

[4] C. B. Meher-Homji, T. R. Mee, Gas Turbine Power Augmentation by Fogging of Inlet Air, Proceeding of the 28th Turbomachinery Sysmposium.

[5] M. Chaker, C. B. Meher-Homji, T. R. Mee, Inlet fogging of gas turbineengines - Part A: fog droplet thermodynamics, heat transfer and practicalconsiderations, Proceeding of ASME Turbo Expo 2002, June 3-6, Amsterdam, The Netherlands.

[6] C. B. Meher-Homji, T. R. Mee, Inlet fogging of gas turbine engines - Part B:practical considerations, control and O\&M aspects, Proceeding of ASME TurboExpo 2000, May 8-11, Munich, Germany.

[7] R. Hosseini, A. Beshkani, M. Soltani, Performance improvement of gasurbines of Fars (Iran) combined cycle

power plant by intake air cooling using atmedia evaporative cooler. Energy Conversion and Management 48 (2007)1055e1064.

[8] A. Behdashti, M. Ebrahimpour2, B. Vahidi, V.Omidipour, A.Alizadeh, FieldExperiments and Technical Evaluation of an Optimized Media EvaporativeCooler for Gas Turbine Power Augmentation, Journal of Applied Research andTechnology, Vol. 10 No.3, June 2012.

[9] P. E. Sanjeev Jolly, Wet compression - A powerful means of enhancingcombustion turbine capacity, Presented at Power-Gen international, Orlando,Florida, December 10-12, 2002.

[10] A. M. Al-Ibrahim, A. Varnham, A review of inlet air-cooling technologies forenhancing the performance of combustion turbines in Saudi Arabia, AppliedThermal Engineering, 30 (2010), 1879-1888.

[11] Mohammad M. EL-AWAD, A computer based model for gas turbine poweraugmentation by inlet air cooling and water/steam injection, STROJN'ICKY ${ }^{\sim}$ CASOPIS, 59, 2008, c. 4.

[12] A comparative assessment of alternative combustion turbine inlet air coolingsystems, Prepared for US department of Energy, Feb. 1996, PNNL-10966.

[13] Y. H. Zurigat, B. Dawoud, J. Bortmany, On the technical feasibility of gasturbine inlet air cooling utilizing thermal energy storage, International journal ofenergy research, 30 (5), 291-305. 